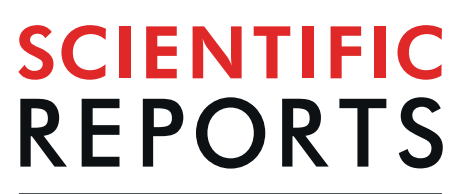

natureresearch

\title{
Fractionated head and neck irradiation impacts taste progenitors, differentiated taste cells, and Wnt/ $\beta$-catenin signaling in adult mice
}

\begin{abstract}
Dany Gaillard $\mathbb{1}^{1,2^{*}}$, Lauren A. Shechtman ${ }^{1,2}$, Sarah E. Millar ${ }^{3,4,5}$ \& Linda A. Barlow ${ }^{1,2 *}$
Head and neck cancer patients receiving conventional repeated, low dose radiotherapy (fractionated IR) suffer from taste dysfunction that can persist for months and often years after treatment. To understand the mechanisms underlying functional taste loss, we established a fractionated IR mouse model to characterize how taste buds are affected. Following fractionated IR, we found as in our previous study using single dose IR, taste progenitor proliferation was reduced and progenitor cell number declined, leading to interruption in the supply of new taste receptor cells to taste buds. However, in contrast to a single dose of IR, we did not encounter increased progenitor cell death in response to fractionated IR. Instead, fractionated IR induced death of cells within taste buds. Overall, taste buds were smaller and fewer following fractionated IR, and contained fewer differentiated cells. In response to fractionated IR, expression of Wnt pathway genes, Ctnnb1, Tcf7, Lef1 and Lgr5 were reduced concomitantly with reduced progenitor proliferation. However, recovery of Wnt signaling post-IR lagged behind proliferative recovery. Overall, our data suggest carefully timed, local activation of Wnt/ $\beta$-catenin signaling may mitigate radiation injury and/or speed recovery of taste cell renewal following fractionated IR.
\end{abstract}

Head and neck cancers represent $\sim 4 \%$ of all cancers in the United States of America ${ }^{1}$. Treatments generally include surgery, chemotherapy and radiotherapy. Radiotherapy consists of small, fractionated X-ray doses of 1-2 Gy administered daily for up to 7 weeks $^{2}$. Although new radiotherapy protocols ${ }^{2}$, including intensity-modulated radiation therapy (IMRT), volumetric modulated arc therapy (VMAT) and image-guided radiation therapy (IGRT), minimize exposure of healthy tissue, side effects remain common. Patients undergoing radiotherapy suffer from nausea, xerostomia (dry mouth), mucositis (oral blistering), difficulty swallowing, as well as taste disturbances including dysgeusia (distorted taste) and ageusia (taste loss) ${ }^{3-6}$. Radiation (IR)-induced taste dysfunction frequently causes depression due to lack of pleasure associated with eating, loss of appetite and motivation to eat, and weight loss from lower nutrient intake $\mathrm{f}^{7-12}$. Thus, taste dysfunction is an important and distressing side effect for head and neck cancer patients ${ }^{13,14}$. Because the mechanisms underlying taste disturbance are poorly understood, targeted treatments to mitigate this serious consequence of radiotherapy have yet to be developed.

Under homeostasis, taste progenitor cells located outside of taste buds continually divide and supply new taste cells to each bud, thereby replacing the steady loss of aged cells ${ }^{15,16}$. We showed previously in mice that a single radiation dose administered to the head and neck induced a dramatic, albeit transient reduction in progenitor cell proliferation ${ }^{17}$, leading to interrupted supply of new taste cells, followed by a transient reduction in differentiated taste cells ${ }^{17}$. While this study was the first to comprehensively explore the impact of IR on taste bud cell renewall ${ }^{17}$,

${ }^{1}$ Department of Cell \& Developmental Biology, University of Colorado Anschutz Medical Campus, Mail Stop 8108, 12801 East 17th Avenue, Aurora, CO, 80045, USA. ${ }^{2}$ Rocky Mountain Taste \& Smell Center, University of Colorado Anschutz Medical Campus, Mail Stop 8108, 12801 East 17th Avenue, Aurora, CO, 80045, USA. ${ }^{3}$ Black Family Stem Cell Institute, Icahn School of Medicine at Mount Sinai, New York, NY, USA. ${ }^{2}$ Department of Cell, Developmental and Regenerative Biology, Icahn School of Medicine at Mount Sinai, New York, NY, USA. ${ }^{5}$ Department of Dermatology, Icahn School of Medicine at Mount Sinai, NewYork, NY, USA. *email: dany.gaillard@cuanschutz.edu; linda.barlow@cuanschutz.edu 
a single dose paradigm does not reflect conventional fractionated IR experienced by patients. In contrast to the rapid recovery of taste bud homeostasis as well as taste function in mice following a single dose ${ }^{17,18}$, patients can suffer from taste disturbance for months and even years following fractionated $\mathrm{IR}^{14,19,20}$. Here, we sought to establish how at a cellular level, taste homeostasis is affected by repeated IR.

The Wnt/ $\beta$-catenin pathway controls the development and maintenance of multiple tissues, and activating mutations of the pathway are associated with the development of cancer ${ }^{21}$. Wnt ligands bind to coreceptors, triggering the release of $\beta$-catenin from a destruction complex, allowing its translocation to the nucleus where it binds LEF/TCF transcription factors to activate transcription of target genes ${ }^{21}$. Wnt/ $\beta$-catenin signaling is also a major regulator of taste bud homeostasis; it is required for progenitor maintenance and proliferation, and functions in taste cell fate decisions ${ }^{16,22-25}$. Additionally, in a host of tissues, Wnt/ $\beta$-catenin signaling functions in regeneration following injury, including IR damage ${ }^{26-34}$; thus here we investigated if and how Wnt signaling in taste epithelium is affected by fractionated IR.

\section{Results}

Fractionated IR results in reduced taste buds in posterior CVP and anterior FFP. Previously, we treated mice with a single 8 Gy IR dose, and assessed taste homeostasis in the CVP at progressive days post-IR $(\mathrm{dpi})^{17}$. Here we wanted to compare the impact of repeated IR to that of single dose assessed at comparable time points as well as determine its effect on taste bud renewal in both the fungiform taste papillae (FFP) of the anterior tongue (AT) and the circumvallate taste papilla (CVP) in the posterior tongue. The head and neck of wildtype mice were repeatedly irradiated (4Gy daily for 5 consecutive days) $)^{35,36}$ and tongues harvested during and at progressive time points following IR. Cryosections were immunolabelled with antiserum against KCNQ1, a general taste cell marker ${ }^{37}$, in order to tally and quantify the size of taste bud profiles in irradiated and control tissue. While both FFP and CVP buds were impacted, the manner in which they were affected differed. CVP taste buds of irradiated mice were smaller than controls at 3 and 10 but not 21 dpi (Fig. 1G,I-L), while irradiated FFP taste buds were not significantly smaller at any time (Fig. 1A,C-F). Instead, FFP taste bud number was reduced over time in irradiated mice (Fig. 1B; 10 and $21 \mathrm{dpi}$ ). Because taste buds were smaller in irradiated CVP taste buds at some post-IR times, counts required Abercrombie correction (methods and reference ${ }^{38}$, Supplementary Fig. S1), revealing that CVP taste bud number was reduced only at $21 \mathrm{dpi}($ Fig. $1 \mathrm{H}, \mathrm{L})$.

Fewer differentiated taste cells populate taste buds of the CVP and FFP after fractionated IR. Murine taste buds are collections of $\sim 60$ elongate taste receptor cells, belonging to 3 morphological types: type I glial-like cells ${ }^{39-41}$, type II sweet, umami, and bitter/high salt cells ${ }^{42-47}$, and type III sour and salt detector cells ${ }^{4-54}$. Because taste buds are reduced in irradiated FFP and CVP, we sought to determine which taste cell types were affected by fractionated IR. Using qRT-PCR, we found marker gene expression for all 3 taste cell types was reduced by fractionated IR, with the kinetics of the IR response differing slightly between CVP and FFP-containing AT epithelium. (1) Type I cells express the ectoATPase, NTPDase $2^{39}$; and expression of Entpd2, which encodes NTPDase2, was reduced in AT epithelium following IR (albeit with transient recovery at $10 \mathrm{dpi}$ ), while in CVP Entpd2 was similarly reduced post-IR, but with recovery by $21 \mathrm{dpi}$ (Fig. 2A,B). Entpd2 expression was unexpectedly again downregulated at 21 dpi in AT, but not CVP (Fig. 2A,B). (2) Plcb2, a general marker of type II cells ${ }^{55}$, was reduced post-IR in both AT and CVP, but only returned to control levels in the CVP (Fig. 2C,D). Type II cells selective for sweet and umami can be distinguished from bitter detecting type II cells by expression of the Tas $1 r 3$ taste receptor. In both AT and CVP epithelium, Tas $1 r 3$ was reduced post-IR; while Tas $1 r 3$ returned to control levels by $10 \mathrm{dpi}$ in both taste fields, its expression in irradiated AT was again downregulated at $21 \mathrm{dpi}$ (Fig. 2E,F). (3) Type III taste cells form presynaptic specializations on afferent nerve fibers, and express markers of synapses including SNAP2 $5^{56}$. In the CVP Snap 25 was downregulated between 2 and $10 \mathrm{dpi}$ (Fig. 2H), while in the AT Snap25 was lower only at 10 dpi (Fig. 2G).

We next determined if and when the number of specific taste cell types was reduced following fractionated IR. We focused on type II and III cells as these are functional taste receptors for the 5 basic tastes, and can be readily quantified (see reference ${ }^{57}$ ). In the FFP, the number of PLC $32^{+}$type II cells was significantly reduced at 10 and $21 \mathrm{dpi}$ (Fig. 3A-E); in the CVP, fewer PLC $\beta 2^{+}$cells were already evident at $3 \mathrm{dpi}$, and while trending lower at 10 and 21 dpi did not differ significantly from controls (Fig. 3F-J). Note PLC $\beta 2^{+}$cells in the CVP had larger nuclei at $21 \mathrm{dpi}$ and thus these counts required Abercrombie correction (Supplementary Fig. S2A,B, uncorrected data shown in Supplementary Fig. S2C). In addition to expressing SNAP25, Type III taste cells accumulate serotonin (5-HT), detectable with 5-HT antiserum ${ }^{58}$. Fractionated IR did not alter the number of 5-HT+ ${ }^{+}$ype III cells in FFP taste buds (Fig. 3K-O). However, 5-HT+ ${ }^{+}$cells were significantly fewer in irradiated CVP at 3 and 21 dpi, with a similar trend at $10 \mathrm{dpi}$ (Fig. 3P-T). Note $5-\mathrm{HT}^{+}$cells in the CVP also had larger nuclei at $10 \mathrm{dpi}$ and thus these counts required Abercrombie correction (Supplementary Fig. S2D,E, uncorrected data shown in Supplementary Fig. S2F). Thus, reduced expression of taste cell marker genes is detectable in both CVP and FFP (Fig. 2) in advance of overt and statistically significant reduction of differentiated type II and III taste cells (Fig. 3).

Fractionated IR affects progenitor proliferation and causes a reduction in progenitor cell number. Following single dose IR, progenitor cell proliferation in the CVP is significantly reduced, interrupting production of new taste cells, and thereby causing a transient reduction in type II and III cells as aging taste cells are lost and not immediately replaced ${ }^{17}$. Here, we assessed progenitor proliferation in both FFP and CVP following fractionated IR via qRT-PCR for Mki6759,60 (Fig. 4A,B). The impact of fractionated IR on Mki67 expression was roughly comparable in AT and CVP epithelium. In general, and consistent with the impact of IR on many renewing epithelia ${ }^{17,35,61-65}$ Mki67 was downregulated during IR and overshot controls in the 2-3 days post-IR, before returning to levels more closely aligned with those of controls (Fig. 4A,B). Interestingly, Mki67 expression in the 


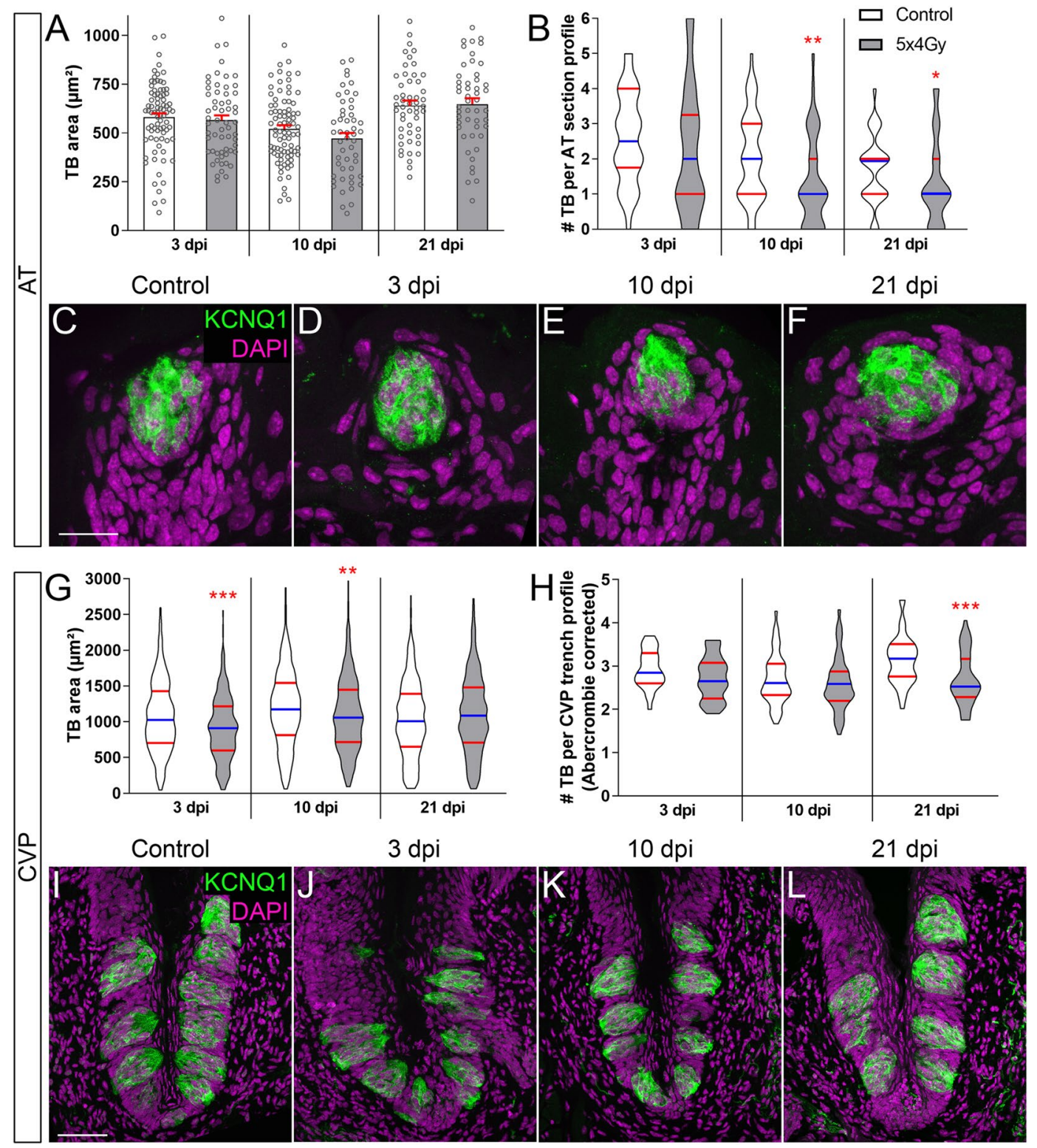

Figure 1. The number, but not size, of FFP taste buds is reduced following fractionated irradiation, while both size and numbers are diminished in the CVP. The area of KCNQ1 ${ }^{+}$FFP taste bud profiles (green) was used as a proxy for taste bud size, and was unaffected in irradiated mice compared to controls (A,C-F). The area of taste bud profiles was significantly smaller in irradiated CVP compared to controls at 3 and $10 \mathrm{dpi}$, and recovered at $21 \mathrm{dpi}(\mathbf{G}, \mathbf{I}-\mathbf{L})$. The number of taste bud profiles remained unchanged in the CVP at 3 and $10 \mathrm{dpi}$, and was slightly reduced at $21 \mathrm{dpi}(\mathbf{H}, \mathbf{I}-\mathbf{L})$. Fewer FFP taste buds were present in irradiated tongues at 10 and $21 \mathrm{dpi}$ (B). Data are represented as violin plots with median (blue line) and $1^{\text {st }}$ and $3^{\text {rd }}$ quartile (red lines), or mean \pm SEM. Mann $\&$ Whitney test in violin plots, Student's t-test in mean \pm SEM graph $(* \mathrm{p}<0.05, * * \mathrm{p}<0.01$, $* * * \mathrm{p}<0.001$ ). Taste bud Eqdiameter (see methods) in control FFP was not significantly different than irradiated FFP at any time points (Mann \& Whitney test, Supplementary Fig. S1A) but taste bud Eqdiameter was significantly smaller in irradiated CVP taste buds at 3 and $10 \mathrm{dpi}$ (Mann \& Whitney test, Supplementary Fig. S1B); therefore, Abercrombie correction was applied to counts of CVP but not FFP taste buds (uncorrected data shown in Supplementary Fig. S1C). Representative pictures are compressed confocal z-stacks. Scale bars $20 \mu \mathrm{m}$ in $(\mathbf{C})$, applies to $(\mathbf{D}-\mathbf{F}), 50 \mu \mathrm{m}$ in (I), applies to (J-L). FFP Control vs IR mice 3 dpi, $\mathrm{N}=4$ vs $3 ; 10 \mathrm{dpi}$, $\mathrm{N}=4$ vs $4 ; 21 \mathrm{dpi} \mathrm{N}=3$ vs 4 . CVP Control vs IR mice 3 dpi, $\mathrm{N}=4$ vs $3 ; 10 \mathrm{dpi}, \mathrm{N}=6$ vs $6 ; 21 \mathrm{dpi} \mathrm{N}=6$ vs 7 . (A) Control vs IR FFP taste bud profiles $3 \mathrm{dpi}, \mathrm{n}=81$ vs $59 ; 10 \mathrm{dpi}, \mathrm{n}=83$ vs $51 ; 21 \mathrm{dpi}, \mathrm{n}=51$ vs 49 . (B) Control vs IR FFP section profiles $3 \mathrm{dpi}, \mathrm{n}=30$ vs $26 ; 10 \mathrm{dpi}, \mathrm{n}=40$ vs $40 ; 21 \mathrm{dpi}, \mathrm{n}=30$ vs 38 . (G) Control vs IR CVP taste bud profiles $3 \mathrm{dpi}, \mathrm{n}=350$ vs $244 ; 10 \mathrm{dpi}, \mathrm{n}=530$ vs $505 ; 21 \mathrm{dpi}, \mathrm{n}=525$ vs 495 . (H) Control vs IR trench profiles $3 \mathrm{dpi}, \mathrm{n}=30$ vs $24 ; 10 \mathrm{dpi}, \mathrm{n}=48$ vs $48 ; 21 \mathrm{dpi}, \mathrm{n}=43$ vs 46 . 

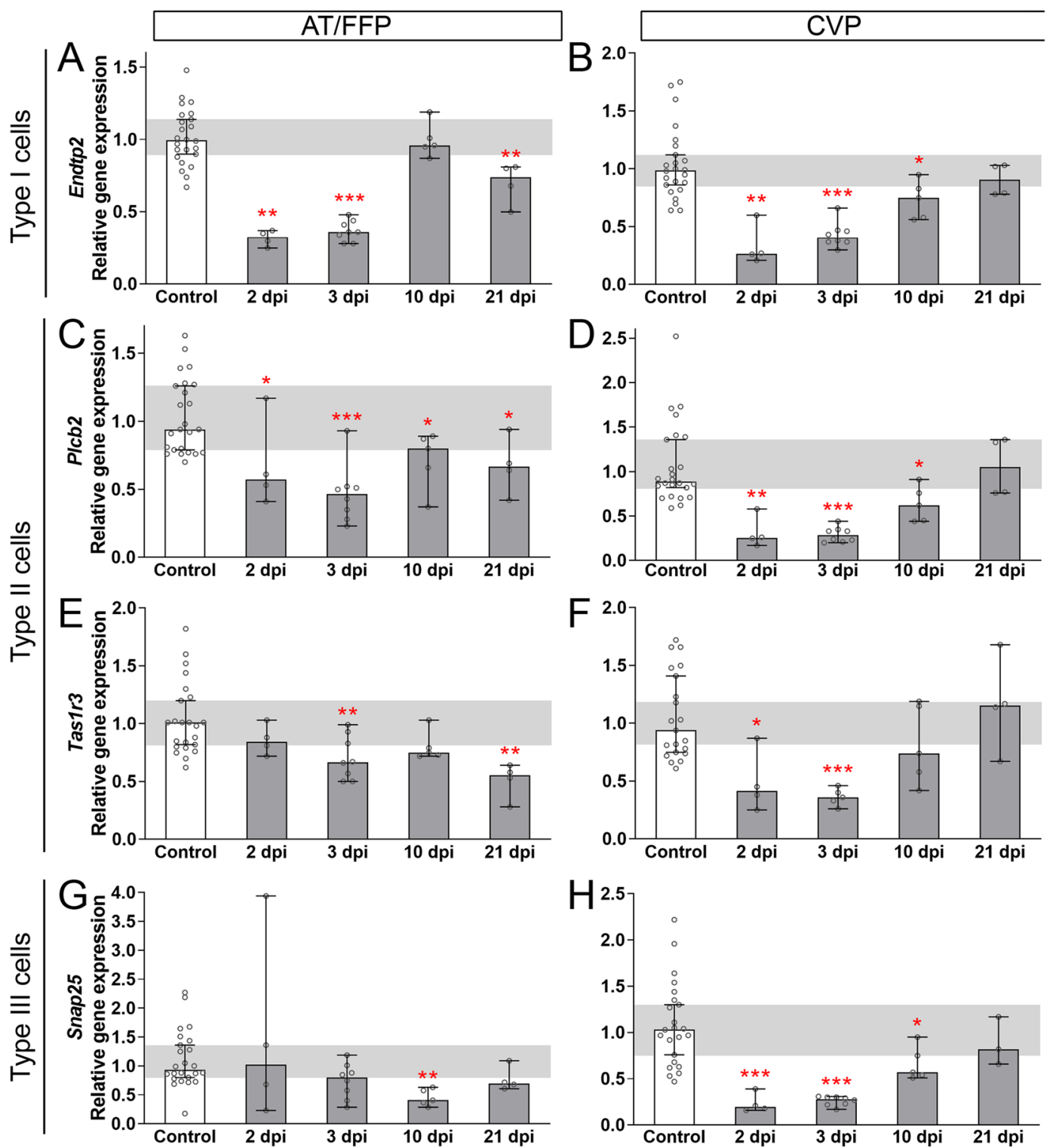

Figure 2. Markers of all 3 differentiated taste cell types are transiently diminished after fractionated irradiation. Expression of markers of all 3 differentiated taste cell types, Entpd 2 for type I, Plcb2 and Tas1r3 for type II, and Snap 25 for type III cells was quantified by qRT-PCR. In AT, Entpd 2 expression was reduced shortly after IR, transiently recovered, and then was secondarily reduced at $21 \mathrm{dpi}(\mathbf{A})$. Plcb2 (C) and Tas $1 r 3(\mathbf{E})$ were significantly reduced at 2-3 dpi, with some recovery, but secondary reduction was observed at 21 dpi. (G) In AT, Snap25 was reduced transiently at $10 \mathrm{dpi}$. In CVP, Entpd2, PLCb2, Tas1r3 and Snap25 were all reduced following IR but recovered by $21 \mathrm{dpi}(\mathbf{B}, \mathbf{D}, \mathbf{F}, \mathbf{H})$. Data are represented as median (vertical bars) with $95 \%$ confidence interval (error bars), and individual points (scatter plot). Horizontal grey bars represent control $95 \%$ confidence interval. Mann \& Whitney test $(* \mathrm{p}<0.05$, ** $\mathrm{p}<0.01, * * * \mathrm{p}<0.001)$. (A-H) (Controls vs IR mice) $2 \mathrm{dpi}, \mathrm{N}=5$ vs $4 ; 3 \mathrm{dpi}, \mathrm{N}=9$ vs $8 ; 10 \mathrm{dpi}, \mathrm{N}=6$ vs $5 ; 21 \mathrm{dpi}, \mathrm{N}=4$ vs 4 .

AT remained elevated at $10 \mathrm{dpi}$ but exhibited a second downregulation at $21 \mathrm{dpi}$; a secondary reduction in Mki67 transcripts was not evident in the CVP (Fig. 4A,B).

We also quantified the proportion of $\mathrm{Ki} 67^{+}$progenitor cells in immunostained sections of CVP tissue at IR Day 3 and 2 dpi when Mki67 was reduced and upregulated, respectively (see Fig. 4B). Ki67 ${ }^{+}$and total (DAPI ${ }^{+} /$ $\mathrm{Krt}^{-}$) basal cells along the basement membrane (marked with E-cadherin - not shown, outlined with yellow dotted line) were tallied to determine both the total number of basal progenitor cells and the proportion engaged in the cell cycle (proliferation index $=\mathrm{Ki} 7^{+}$basal cells/DAPI ${ }^{+}$basal cells $* 100^{17}$ ). The proportion of Ki67 ${ }^{+}$cells was significantly reduced both during (IR Day 3 ) and after IR (2 dpi) compared to controls (Fig. 4C,E-G), as was the total number of progenitor cells (Fig. 4D,E-G). Note progenitor nuclei were significantly larger at $2 \mathrm{dpi}$ (Supplementary Fig. S3A) necessitating Abercrombie correction (Uncorrected data shown in Supplementary Fig. S3B). However, the proliferation index and Mki67 expression were inversely correlated at 2 dpi (Fig. 4B,C), 

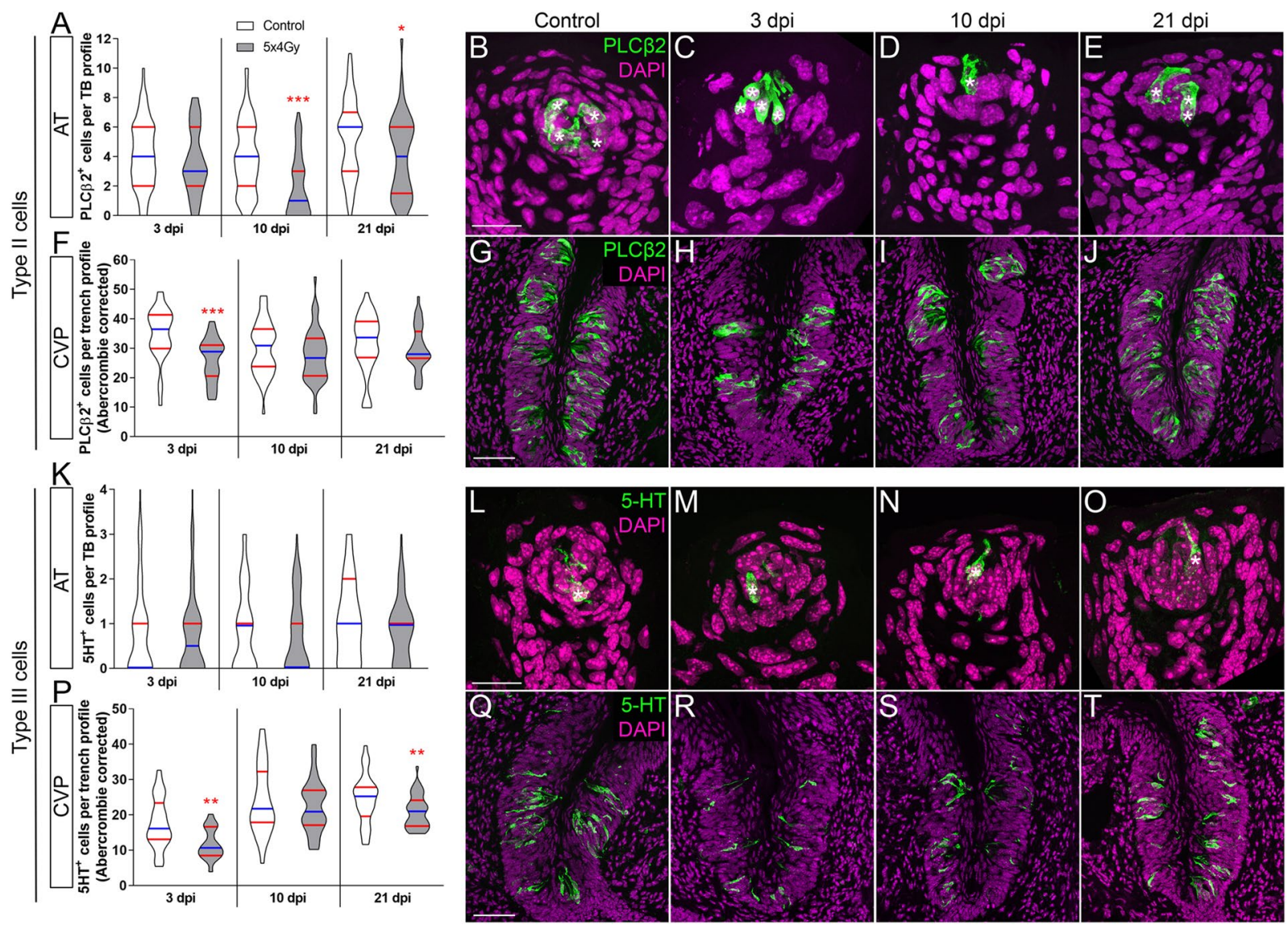

Figure 3. The number of type II and type III cells are differentially diminished after fractionated irradiation, and with different temporal patterns in AT vs. CVP. PLC $\beta 2^{+}$type II cell number (green) per taste bud was significantly reduced in FFP at 10 and $21 \mathrm{dpi}(\mathbf{A}-\mathbf{E})$, but only at 3 dpi in the CVP (F-J). 5-HT ${ }^{+}$type III cell numbers in FFP were not affected by IR $(\mathbf{K}-\mathbf{O})$. In CVP, $5-\mathrm{HT}^{+}$cells (green) per trench profile were significantly diminished at 3 and 21 dpi (P-T). Asterisks indicate PLC $\beta 2^{+}$and $5-\mathrm{HT}^{+}$cells in FFP. Representative pictures are compressed z-stacks. Scale bars $20 \mu \mathrm{m}$ for (B-E), (L-O), $50 \mu \mathrm{m}$ for $(\mathbf{G}-\mathbf{J}, \mathbf{Q}-\mathbf{T})$. Data are represented as violin plots with median (blue line) and $1^{\text {st }}$ and $3^{\text {rd }}$ quartile (red lines). Mann \& Whitney test $(* \mathrm{p}<0.05$, $* * \mathrm{p}<0.01, * * * \mathrm{p}<0.001)$. In the FFP, nuclear size of $\mathrm{PLC} \beta 2^{+}$and $5 \mathrm{HT}^{+}$cells did not differ in control versus irradiated at any time points (Mann \& Whitney test, Supplementary Fig. S2A,D), while in the CVP PLC $\beta 2^{+}$ and $5-\mathrm{HT}^{+}$cell nuclei were larger in irradiated tongues at 21 and $10 \mathrm{dpi}$, respectively (Student's t-test, MannWhitney test, respectively. Supplementary Fig. S2B,E); therefore, Abercrombie correction was applied to CVP taste cell counts (see Methods; uncorrected data in Supplementary Fig. S2C,F). (A) FFP Controls vs IR mice ( $\mathrm{N}=$ mice, $\mathrm{n}=$ taste bud profiles) $3 \mathrm{dpi} \mathrm{N}=4$ vs $3, \mathrm{n}=81$ vs $59 ; 10 \mathrm{dpi} \mathrm{N}=4$ vs $4 \mathrm{n}=83$ vs $52 ; 21 \mathrm{dpi} \mathrm{N}=3$ vs 4 $\mathrm{n}=51$ vs 49 . (B) CVP Controls vs IR $(\mathrm{N}=$ mice, $\mathrm{n}=$ trench profiles) $3 \mathrm{dpi} \mathrm{N}=4$ vs $3, \mathrm{n}=31$ vs $22 ; 10 \mathrm{dpi}, \mathrm{N}=6$ vs $6, \mathrm{n}=48$ vs $48 ; 21$ dpi $\mathrm{N}=6$ vs $7, \mathrm{n}=45$ vs 46 . (K) FFP Controls vs IR ( $\mathrm{N}=$ mice, $\mathrm{n}=$ taste bud profiles) 3 dpi $\mathrm{N}=4$ vs $3, \mathrm{n}=69$ vs $88 ; 10$ dpi $\mathrm{N}=4$ vs $4, \mathrm{n}=85$ vs $53 ; 21$ dpi $\mathrm{N}=3$ vs $4, \mathrm{n}=57$ vs 50 . (P) CVP Controls vs IR ( $\mathrm{N}=$ mice, $\mathrm{n}=$ trench profiles) $3 \mathrm{dpi} \mathrm{N}=4$ vs $3, \mathrm{n}=32$ vs $18 ; 10 \mathrm{dpi} \mathrm{N}=4$ vs $4, \mathrm{n}=30$ vs $26 ; 21 \mathrm{dpi}, \mathrm{N}=6$ vs 7 , $\mathrm{n}=32$ vs 42 .

indicating that proliferative recovery at the transcript level begins in advance of detection of increased Ki67 ${ }^{+}$ expressing cells ${ }^{66}$.

Because radiotherapy is known to damage salivary glands, we assessed Ki67 immunostaining in the minor salivary glands associated with the CVP, the Von Ebner's glands (VEG). While proliferation is robust in control glands, there were many fewer $\mathrm{Ki}^{+} 7^{+}$cells in irradiated VEG at IR Day 3. Intriguingly, $\mathrm{Ki}^{6} 7^{+}$cells appeared to rebound at 2 dpi (Supplementary Fig. S3C-H, yellow arrows).

Progenitor proliferation is reduced following single dose irradiation, due in part to induction of progenitor cell death ${ }^{17}$. To test here if progenitor death likewise increases following fractionated IR, Noxa transcripts (Pmaip1, marker of $\mathrm{p} 53$-mediated cell death ${ }^{67}$ ) in AT and CVP epithelia were quantified via qRT-PCR. In both taste fields, Noxa was highly upregulated immediately at IR Day 1 and remained elevated during and post-IR before returning to control levels at 21 and $10 \mathrm{dpi}$ in AT and CVP, respectively (Fig. 5A,B). We found previously that after single dose IR, progenitor cells made up the majority of dying cells in the CVP, which was maximal at 18 hours post-IR, with no evidence of taste cell death ${ }^{17}$. Surprisingly, fractionated IR did not induce discernible progenitor cell death. Using Keratin (Krt) 5 immunostaining to label basal progenitors ${ }^{15,16}$, we found that the number of 

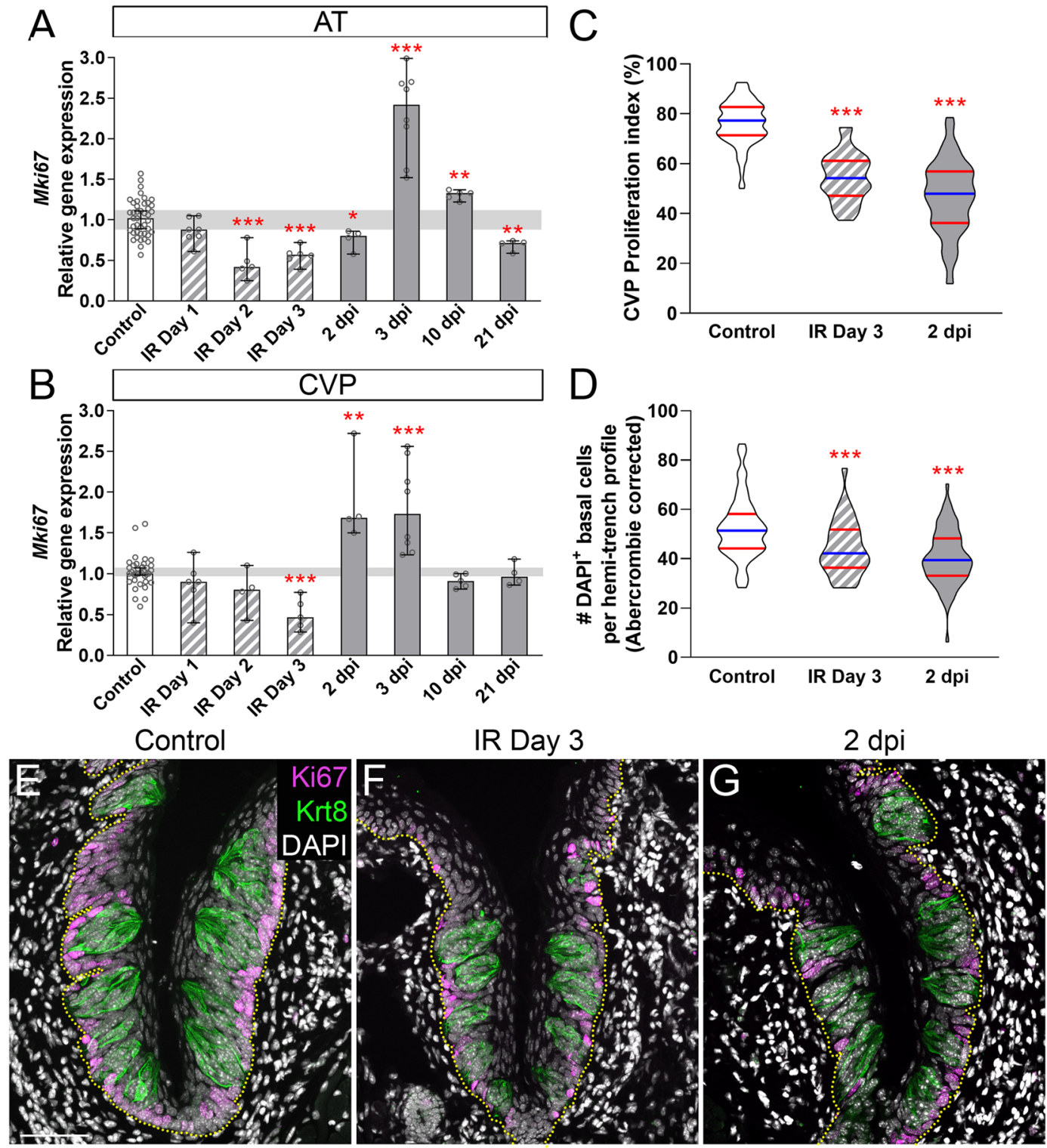

Figure 4. Fractionated irradiation reduces proliferation and causes an overall reduction in basal progenitor cell number. (A) In AT, Mki67 expression was downregulated during (striped bars) (IR Day 2 and 3) and shortly after (gray bars) (2 dpi) fractionated IR, then substantially overshot controls (white bar) before a second drop in expression at $21 \mathrm{dpi}$. (B) In the CVP, Mki67 expression was significantly downregulated at IR Day 3, overshot controls at 2-3 dpi, and returned to control levels at $10 \mathrm{dpi}$. (C) In the CVP, fractionated irradiation caused a significant reduction in the Proliferation Index (\#Ki67 $7^{+}$basal cells/\#DAPI ${ }^{+}$basal cells) and led to significantly fewer total $\mathrm{DAPI}^{+}$progenitor cells along the basement membrane (yellow dotted line) (D). The size of basal nuclei in control CVP was significantly different in irradiated CVP at 2 dpi (Mann \& Whitney test, Supplementary Fig. S3A), and thus required Abercrombie correction (see Methods, uncorrected data in Supplementary Fig. S3B). (E-G) Representative images are compressed z-stacks of CVP sections immunostained for Ki67 (magenta), Krt8 (taste buds; green), and DAPI counterstained (white). Scale bar $50 \mu \mathrm{m}$ for $(\mathbf{E}-\mathbf{G}) .(\mathbf{A}, \mathbf{B})$ Data are represented as median (bars) with $95 \%$ confidence interval (error bars), and individual points (scatter plot). Horizontal grey bars represent control $95 \%$ confidence interval. Mann \& Whitney test $(* \mathrm{p}<0.05, * * \mathrm{p}<0.01, * * * \mathrm{p}<0.001$ ). N AT (Controls vs IR mice) Day 1, 6 vs 7; Day 2, 5 vs 5, Day 3, 8 vs $6 ; 2$ dpi, 5 vs $4 ; 3$ dpi, 9 vs $8 ; 10$ dpi, 6 vs $5 ; 21$ dpi, 4 vs 4 . N CVP (Controls vs IR mice) IR Day 1, 5 vs 6; IR Day 2, 4 vs 4; IR Day 3, 3 vs 5; 2 dpi, 5 vs 4; 3 dpi, 9 vs $8 ; 10$ dpi, 6 vs 5; 21 dpi, 4 vs 4. (C,D) Data are represented as violin plots with median (blue line) and $1^{\text {st }}$ and $3^{\text {rd }}$ quartile (red line). Mann \& Whitney test $(* \mathrm{p}<0.05$, $* * \mathrm{p}<0.01, * * * \mathrm{p}<0.001)$. Controls vs IR $(\mathrm{N}=$ mice, $\mathrm{n}=$ trench profiles) IR Day $3 \mathrm{~N}=6$ vs $5, \mathrm{n}=73$ vs $33 ; 2$ dpi $\mathrm{N}=4$ vs $5, \mathrm{n}=50$ vs 70 .

$\mathrm{TUNEL}^{+} / \mathrm{Krt5}^{+}$progenitor cells per trench profile was extremely low and did not differ between controls and irradiated CVP during or following IR (Mann and Whitney test, IR day $2 \mathrm{p}=0.389$, IR day $3 \mathrm{p}=0.277,2 \mathrm{dpi}$ $\mathrm{p}=0.142$, respectively; no $\mathrm{TUNEL}^{+}$progenitors per CVP of 3-6 control mice versus $1-2 \mathrm{TUNEL}^{+}$progenitors 

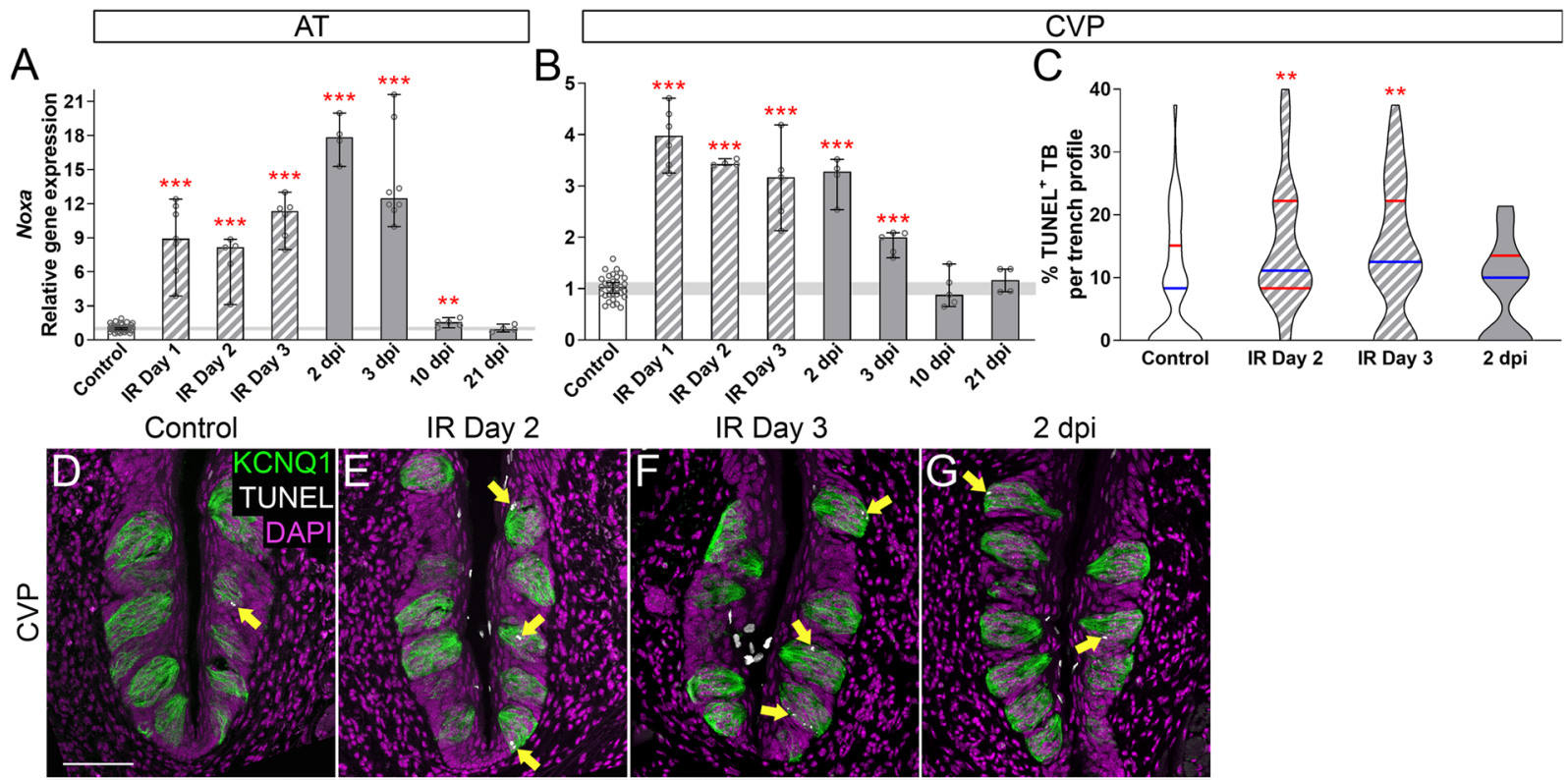

IR Day 3

2 dpi
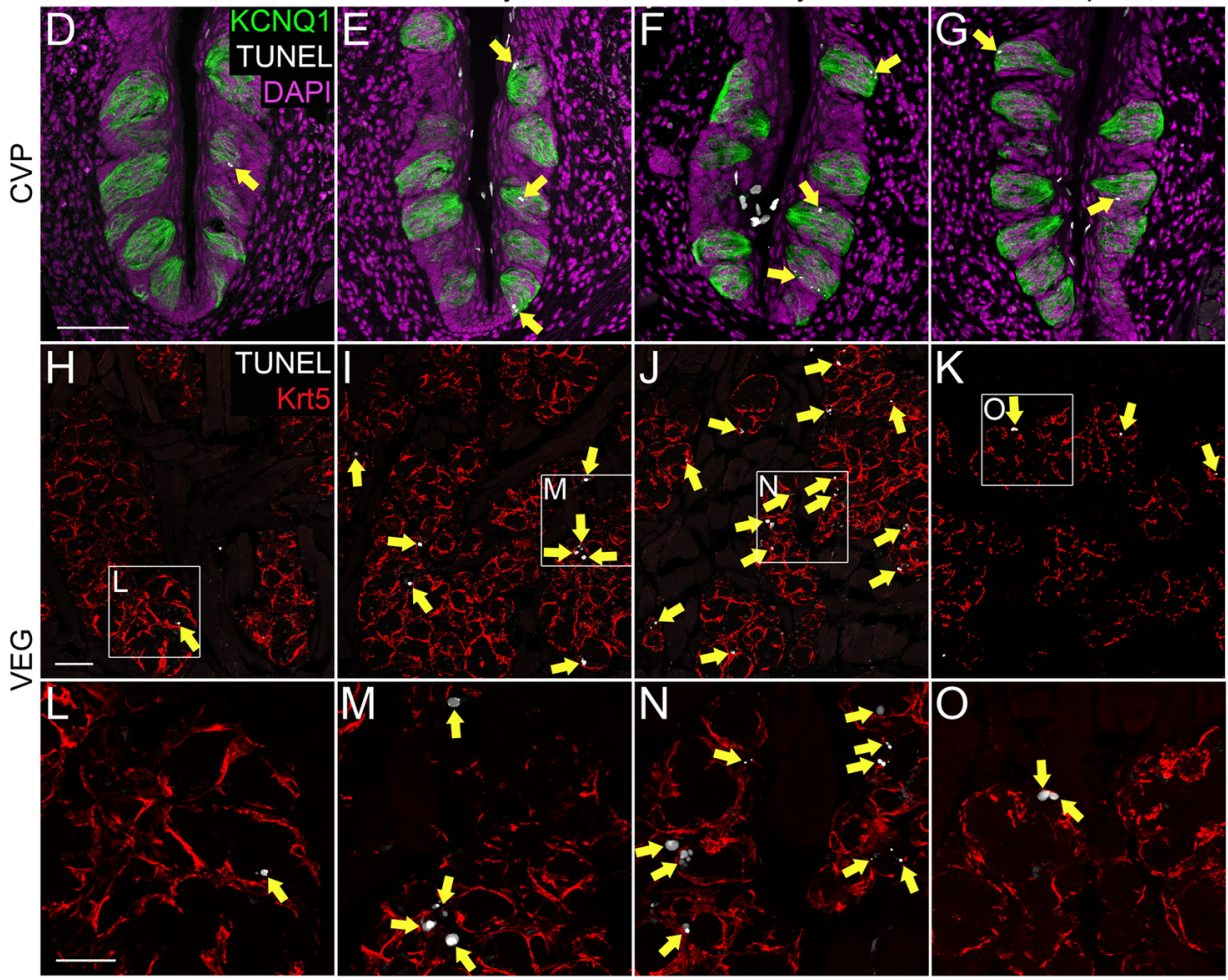

Figure 5. Differentiated cells, but not progenitor cells undergo cell death during fractionated irradiation. $(\mathbf{A}, \mathbf{B})$ In AT and CVP, Noxa expression was highly upregulated during (striped bars) and after (gray bars) fractionated irradiation, before returning to control levels at 21 dpi and 10 dpi, respectively. (C,D-G) Quantification of $\mathrm{TUNEL}^{+}$cells in CVP sections immunostained for Krt5 to mark basal progenitors (DAPI magenta and not shown) and KCNQ1 to mark taste buds (green) revealed that $\mathrm{TUNEL}^{+}$cells (white; yellow arrows) were encountered only in CVP taste buds, and not in basal cells (see text). The proportion of TUNEL ${ }^{+}$taste buds per CVP trench profile was significantly increased during fractionated irradiation (striped violins), and returned to control levels at 2 dpi. (H-O) TUNEL ${ }^{+}$cells were also substantially increased in the Von Ebner's glands (white, yellow arrows; Krt5 red) during IR compared to controls, and appeared to recover at 2 dpi ( $\mathbf{H}, \mathbf{K}, \mathbf{L}, \mathbf{O})$. Representative pictures are compressed $z$-stacks. Scale bars $50 \mu \mathrm{m}$ in (D) applies to (E-H) applies to (I-K), and $25 \mu \mathrm{m}$ in (L) applies to (M-O). (A,B) Data are represented as median (bars) with $95 \%$ confidence interval (error bars), and individual points (scatter plot). Horizontal grey bars represent control $95 \%$ confidence interval.

Mann \& Whitney test $(* \mathrm{p}<0.05, * * \mathrm{p}<0.01, * * * \mathrm{p}<0.001$ ). (A) AT (Controls vs IR mice) IR Day $1 \mathrm{~N}=6$ vs 7 ; IR Day $2 \mathrm{~N}=5$ vs 5 , IR Day $3 \mathrm{~N}=8$ vs $6 ; 2$ dpi $\mathrm{N}=5$ vs $4 ; 3$ dpi $\mathrm{N}=9$ vs $8 ; 10$ dpi $\mathrm{N}=6$ vs $5 ; 21$ dpi $\mathrm{N}=4$ vs 4 . (B) CVP (Controls vs IR mice) IR Day $1 \mathrm{~N}=5$ vs 6; IR Day $2 \mathrm{~N}=4$ vs 4 ; IR Day $3 \mathrm{~N}=3$ vs 5 ; 2 dpi $\mathrm{N}=5$ vs 4 ; 3 dpi $\mathrm{N}=9$ vs $8 ; 10 \mathrm{dpi} \mathrm{N}=6$ vs $5 ; 21 \mathrm{dpi} \mathrm{N}=4$ vs 4 . (C). Data are represented as violin plots with median (blue line) and $1^{\text {st }}$ and $3^{\text {rd }}$ quartile (red lines). Mann \& Whitney test $(* \mathrm{p}<0.05, * * \mathrm{p}<0.01, * * * \mathrm{p}<0.001)$. Controls vs IR ( $\mathrm{N}=$ mice, $\mathrm{n}=$ trench profiles) IR Day $2 \mathrm{~N}=3$ vs $3, \mathrm{n}=22$ vs 27 ; IR Day $3 \mathrm{~N}=6$ vs $5, \mathrm{n}=48$ vs $39 ; 2$ dpi $\mathrm{N}=3$ vs $3, \mathrm{n}=22$ vs 21 .

per CVP trench of 3-5 irradiated mice). Cell death was also assessed via expression of Cleaved Caspase3, a ubiquitous marker of apoptotic cell death ${ }^{68,69}$. Consistent with the TUNEL data, Caspase $3^{+}$progenitor cells were rare, and their numbers did not differ between controls and irradiated CVP (Mann and Whitney test, IR Day $2 \mathrm{p}=1$, IR Day $3 \mathrm{p}=1$, 2 dpi $\mathrm{p}=0.232 ; 0$ Caspase $3^{+}$progenitors per CVP of 3-6 control mice versus 1 Caspase $3^{+}$progenitor per CVP trench of 3-5 irradiated mice). 
Instead, upon fractionated IR, we observed a significant increase in $\mathrm{TUNEL}^{+}$cells inside of taste buds during (IR Days 2 and 3), but not following IR (3 dpi; Fig. 5C,D-G yellow arrows). Likewise, fractionated IR was associated with a higher proportion of taste buds with Cleaved Caspase $3^{+}$cells on IR Day 2, with a trend at IR Day 3 (Mann and Whitney, $\mathrm{p}=0.08$. Supplementary Fig. S4A,B-E yellow arrows). In sum, these data suggest that progenitor cell death does not contribute to the decline in progenitors and their proliferation; rather repeated IR induces death of cells within taste buds.

In the AT, where Noxa expression was also highly upregulated during and following fractionated IR, we likewise observed limited TUNEL ${ }^{+}$cells in and around FFP taste buds; specifically, the proportion of taste buds with $\mathrm{TUNEL}^{+}$cells was comparable between control and irradiated mice during IR (IR Day 3, Supplementary Fig. S4F), as was the number of TUNEL ${ }^{+}$progenitor cells residing at the basement membrane one cell diameter from taste buds (Mann and Whitney test, $\mathrm{p}=0.315,3 \mathrm{TUNEL}^{+}$progenitors per FFP of 3 control mice versus $1 \mathrm{TUNEL}^{+}$progenitor per FFP of 3 irradiated mice). Further, as AT epithelium analyzed for Noxa expression comprises both FFP and non-taste epithelium, we assessed TUNEL ${ }^{+}$cells in non-taste epithelium of sections of AT. Similarly, fractionated IR triggered some cell death, albeit not significantly $(\mathrm{p}=0.071$, Supplementary Fig. S4G-I).

We also assessed the extent of radiation-induced cell death in the VEG, the minor salivary glands associated with the CVP, via TUNEL and Cleaved Caspase 3 staining. In controls, TUNEL $^{+}$and Caspase $3^{+}$cells were extremely sparse (Fig. 5H,L; Supplementary Fig. S4J,N) but were readily detected in VEG acini especially during IR (Fig. 5I-K,M-O; Supplementary Fig. S4J-Q).

Wnt/ $\beta$-catenin signaling is altered in irradiated taste epithelium consistent with a role in recovery of taste cell differentiation but not of progenitor proliferation. In taste epithelium, Wnt/ $\beta$-catenin signaling is required for progenitor survival and proliferation, and regulates taste cell fate decisions prior to differentiation ${ }^{16,22-24}$. Because proliferation of taste progenitors was substantially perturbed by fractionated IR, we explored if, when and how expression levels of $\beta$-catenin (Ctnnb1), and Wnt target genes Lef1 and $T c f 7^{23,70}$ were impacted. Ctnnb1 and Lef1 expression levels dropped during IR, were suppressed for several days post-IR, and then were comparable to controls by 10 dpi in both AT (Fig. 6A,C) and CVP (Fig. 6B,D). While $T c f 7$ expression was reduced in both AT and CVP, this reduction was less extensive than for Lef1 and Ctnnb1 (Fig. 6E,F); in AT, Tcf7 was briefly downregulated post-IR (2, 3 dpi), while in CVP Tcf7 expression was only minimally affected on IR Day 3. In the CVP, Lgr5 is expressed by taste progenitor cells that give rise to differentiated taste cells $\mathrm{s}^{71,72}$ and is a mediator, as well as a transcriptional target of the Wnt pathway ${ }^{73}$. Lgr5 expression mirrored that of Lef1 in the CVP; it was downregulated during and after irradiation but returned to control levels at $21 \mathrm{dpi}$ (Fig. 6G). $L g r 5$ is not expressed by FFP progenitors ${ }^{74}$ but in the AT, we observed a significant secondary decrease in Ctnnb1, Tcf7 and Lef1 at $21 \mathrm{dpi}$, reminiscent of secondary reductions at 21 dpi in expression of Entpd2 (type I taste cells, Fig. 2A), Plcb2 and Tas1r3 (type II taste cells Fig. 2C,E), and Mki67 (proliferation Fig. 4A), suggesting that a longer term perturbation in Wnt pathway activity underlies a secondary decline in FFP taste bud renewal.

\section{Discussion}

Taste dysfunction is an exceedingly common side effect of conventional radiation therapy for head and neck cancers. Here, we developed and characterized a fractionated irradiation protocol in mice to explore mechanisms underlying functional taste loss experienced by patients during and after radiotherapy. We show that, unlike single dose irradiation which leads to progenitor death, fractionated irradiation triggered death of cells within taste buds and did not affect survival of progenitors. However, similarly to single dose IR, repeated irradiation represses proliferation and leads to fewer progenitors. Consequently, fewer new type II and III taste receptor cells are produced. This reduction in new cell supply, combined with death of taste cells leads to smaller and fewer taste buds following IR. Fractionated irradiation also triggers cell death and reduces proliferation in the minor Von Ebner's salivary glands associated with the CVP. Interestingly, we find that onset of reduced Mki67 expression is associated with $\mathrm{Wnt} / \beta$-catenin downregulation, suggesting that $\mathrm{Wnt} / \beta$-catenin signaling is important to maintain proliferation during radiation exposure. However, following fractionated irradiation proliferation recovers in advance of upregulation of Wnt signaling, suggesting other signaling pathways must govern proliferative recovery. Finally, Wnt signaling levels are restored prior to upregulation of markers of differentiated taste cells, suggesting Wnt signaling may support reestablishment of taste cell differentiation following radiation injury.

The impact of IR on taste bud homeostasis is more prolonged in FFP compared to CVP. Our data suggest the impact of fractionated IR on taste bud renewal persists longer in the anterior FFP than the posteriorly located CVP. While by most measures CVP taste buds recovered within 21 days after fractionated IR, the AT exhibited secondary reductions in taste cells and taste cell gene expression, as well as Mki67 expression, suggesting that repeated radiation exposure may lead to long-term disruption of FFP taste cell homeostasis. This effect may be due to a relatively larger amount of radiation delivered to the AT than CVP in our experimental paradigm, as the CVP is located deep in the oral cavity and surrounded by more teeth and bone that can absorb radiation due to their higher density ${ }^{75,76}$. However, data from other cancer therapies as well as genetic studies suggest that FFP homeostasis may be intrinsically more prone to perturbation. In mice, for example, systemic administration of cyclophosphamide, used in the treatment of many cancers ${ }^{77}$ and the cause of substantial dysgeusia for patients ${ }^{78,79}$, has a greater negative impact on FFP taste buds compared to CVP ${ }^{80}$. Likewise, Sonidegib, a Hedgehog pathway inhibitor used to treat basal cell carcinoma patients that also causes significant taste disturbance ${ }^{81-83}$, leads to taste bud loss in both FFP and CVP in mice ${ }^{84}$. However following cessation of Sonidegib, CVP taste buds regenerate in normal numbers, while only partial recovery of FFP taste buds is observed up to 9 months later ${ }^{84}$. Finally, in a genetic model, we found that FFP taste cell renewal is more sensitive to loss of $\beta$-catenin than that of $\mathrm{CVP}^{23}$. What might account for this differential sensitivity? 


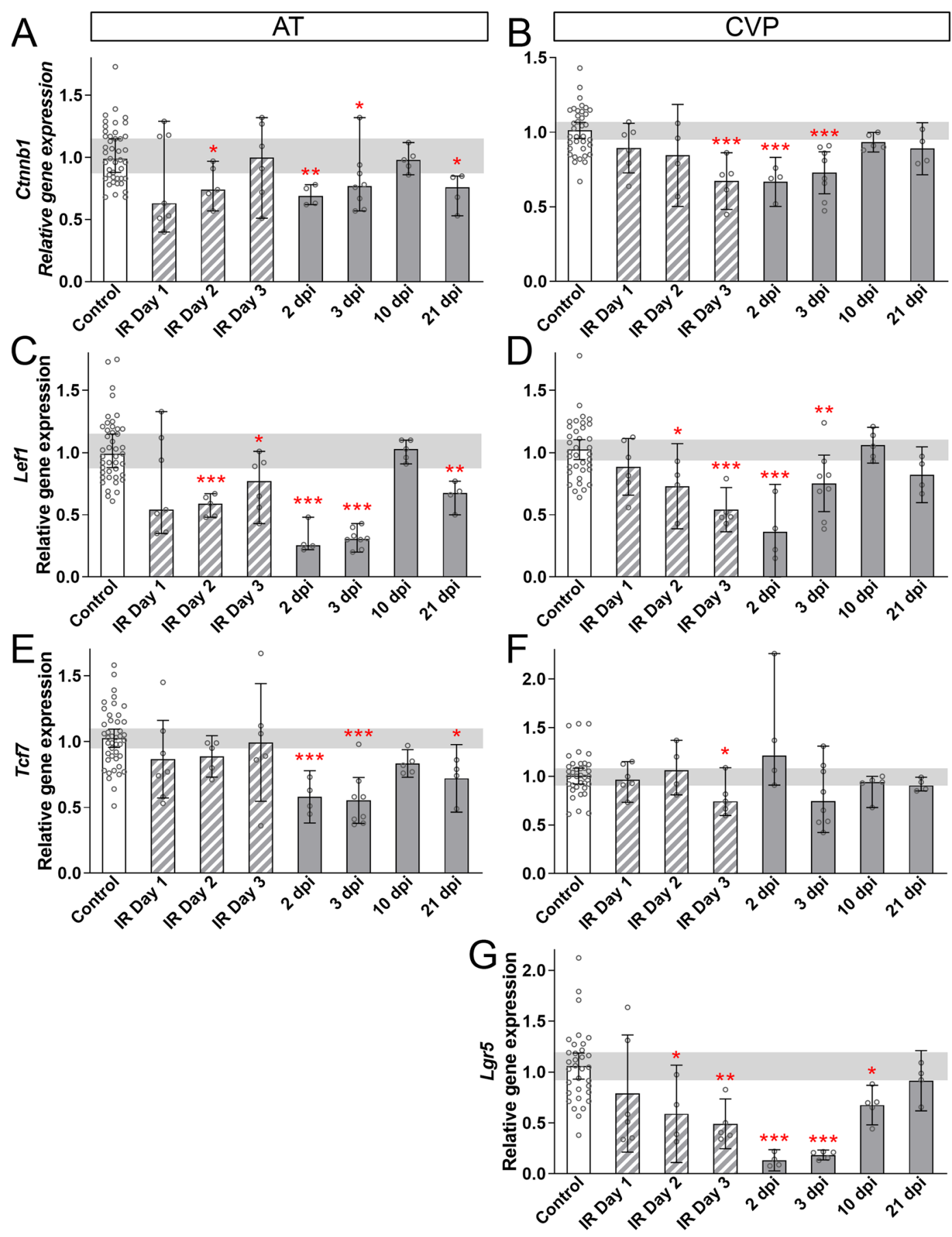

Figure 6. Wnt signaling genes are downregulated during and after irradiation. (A,C) In AT epithelium, Ctnnb1 and Lef1 were reduced during (striped bars) and after (gray bars) fractionated IR, with transient recovery at 10 dpi. (E) In AT, Tcf7 was downregulated but only after IR, with transient recovery at 10 dpi. (B,D) In CVP epithelium, Ctnnb1 and Lef1 were downregulated during fractionated IR (striped bars), and returned to control levels post-IR (gray bars) at $10 \mathrm{dpi}$ with no secondary downregulation at $21 \mathrm{dpi}$. Lgr5 is a Wnt target gene expressed by adult taste stem cells in CVP, but not $\mathrm{FFP}^{71}$. Lgr5 expression was similar to Lef1 in response to IR, but with delayed recovery (G). Data are represented as median (bars) (mean in B,D,E,G) with 95\% confidence interval (error bars), and individual points (scatter plot). Horizontal grey bars represent control $95 \%$ confidence interval. Mann \& Whitney test (Student's t-test in B,D,E,G) $\left({ }^{*} \mathrm{p}<0.05, * * \mathrm{p}<0.01, * * * \mathrm{p}<0.001\right)$. AT and CVP (Controls vs IR $\mathrm{N}=$ mice) Day $1, \mathrm{~N}=6$ vs 7 ; Day $2, \mathrm{~N}=5$ vs 5 , Day $3, \mathrm{~N}=8$ vs $6 ; 2$ dpi, $\mathrm{N}=5$ vs $4 ; 3$ dpi, $\mathrm{N}=9$ vs $8 ; 10 \mathrm{dpi}, \mathrm{N}=6$ vs $5 ; 21 \mathrm{dpi}, \mathrm{N}=4$ vs 4 .

Differential gene expression in the CVP compared with the FFP may contribute to the resilience of the CVP to radiation. For example, Lgr5 is expressed by taste progenitor cells in the CVP but not by FFP progenitors ${ }^{74}$. Interestingly, Lgr $5^{+}$cells in the intestine are important for recovery following irradiation ${ }^{85}$. Therefore, although 
Lgr5 expression is greatly downregulated following irradiation in the CVP, residual Lgr5 expression may be sufficient to mitigate the effect of radiation on the CVP compared to the FFP that do not express Lgr5.

The CVP is intimately connected with the Von Ebner's glands (VEG) that release their contents into the CVP trenches ${ }^{86,87}$. FFP taste buds, by contrast, are bathed in saliva secreted into the oral cavity ${ }^{88,89}$. Hence, the specialized VEG may secrete factors that protect CVP taste bud homeostasis ${ }^{86,90-93}$. Substantial evidence indicates VEG secretions can modulate taste responses ${ }^{90,94}$. Additionally, the VEG expresses EGF that promotes CVP proliferation and differentiation in vitro, and TGF $\alpha$ that may protect CVP taste buds from insult ${ }^{95}$. However, salivary glands are also prone to injury by a range of cancer therapies ${ }^{96,97}$. Notably, head and neck cancer patients treated with targeted IR regularly suffer from persistent xerostomia (dry mouth) ${ }^{98,99}$. In mouse models of head and neck IR, irradiated major salivary glands exhibit substantially increased cell death ${ }^{61,62,100}$, have immediately lowered proliferative capacity ${ }^{61-63}$, and persistently reduced salivary function ${ }^{36,61,101}$. Here, we find the Von Ebner's glands associated with CVP also have increased cell death and diminished proliferation following IR but may be able to engage in proliferative recovery following IR (see Supplementary Fig. S3E,H). This level of damage therefore may not be sufficient to eliminate putative VEG support of CVP taste homeostasis. Thus, it remains an open question as to the nature of the differential resilience of FFP and CVP to radiation and other types of injury.

The impact of fractionated IR on taste bud homeostasis differs from that of single high dose IR. In our initial study we selected a single dose of $8 \mathrm{~Gy}$ to assess the cellular dynamics of taste cell renewal in response to radiation injury ${ }^{17}$. In contrast to the higher doses employed in many studies of mouse lingual epithelium $\left(>13 \mathrm{~Gy}^{31,102-107}\right)$, we found this moderate dose was not lethal nor did it induce oral blistering; instead this intermediate IR treatment caused a dramatic reduction in progenitor proliferation, leading to reduced input of new cells into buds ${ }^{17}$. For the current study, we tested several fractionated IR paradigms and selected 5 daily fractions of $4 \mathrm{~Gy}$, for a total dose of $20 \mathrm{~Gy}$. This level of IR (but not $5 \times 5 \mathrm{~Gy}$ for example) did not lead to mouse lethality but did have a similar effect on taste progenitor proliferation. However, despite the much higher total dose, fractionated IR led to a substantially smaller reduction in proliferative index. While a single IR dose reduced the proliferation index to $<20 \%$ of controls at $2 \mathrm{dpi}^{17}, 2 \mathrm{dpi}$ after fractionated IR the proliferation index dropped minimally, to $\sim 70 \%$ of controls (Fig. 4C). Further, during and following fractionated dosing, we found no evidence of IR-induced progenitor cell death (see Fig. $5 \mathrm{C}-\mathrm{G}$ ), while progenitor death was significantly increased following $1 \times 8 \mathrm{~Gy}$. These differences in cell death and proliferative response suggest that different IR protocols elicit distinct injury responses.

In vitro, high levels of UV irradiation trigger apoptosis of skin keratinocytes, while moderate UV exposure spares cells from death, and instead directs keratinocytes to differentiate ${ }^{108}$. Similarly in ventral tongue epithelium of mice, repeated IR depletes the progenitor pool and accelerates epithelial differentiation by inducing increased "abortive" divisions, where progenitors divide to produce 2 differentiated daughters ${ }^{35}$. Thus, we conjecture that in taste epithelium, a single higher dose of irradiation triggers progenitor cell death while repeated lower doses that cause damage below the threshold to induce cell death, may instead drive taste progenitors to differentiate. Intriguingly, we detect TUNEL ${ }^{+}$cells in taste buds during but not after fractionated IR, leading us to hypothesize that these may be new daughter cells derived from damaged progenitors that enter buds but cannot differentiate and/or do not survive. Additionally, lower dose IR may trigger autophagy rather than apoptosis. In a number of cellular models, mild stress induces autophagy that can support cell survival via recycling of damaged organelles ${ }^{109-111}$. Finally, injury-induced autophagy can lead to cellular senescence ${ }^{112}$. Interestingly, a recent study has identified senescence as a major actor in the ulceration response of rat tongue epithelium to high dose irradiation $^{113}$. Thus, the role of senescence in radiation injury and taste homeostasis may prove a fruitful area of investigation.

In contrast to limited evidence of cell death in taste buds and progenitor cells, we observed a substantial increase in dying cells in the minor VEG salivary glands, suggesting that increased apoptosis in the VEG at least partially may account for persistent upregulation of Noxa in CVP epithelium harvested from irradiated mice. However, we also observed sustained upregulation of Noxa in irradiated AT epithelium via qPCR, with limited evidence of cell death in tissue sections; further this epithelium is not invested with salivary glands. One potential explanation is that although Noxa is a major mediator of $\mathrm{p} 53$-mediated apoptosis ${ }^{67}$, it is also involved in promotion of autophagy in cardiomyocytes ${ }^{114}$, suggesting Noxa upregulation in CVP and AT by fractionated IR may reflect induction of autophagy, rather than cell death.

Temporal regulation of Wnt pathway genes may reflect different roles for Wnt signaling in taste regeneration following radiation injury. We have shown that genetic stabilization of the main effector of the Wnt pathway, $\beta$-catenin, in $\mathrm{Krt}^{+} 5^{+}$progenitors activates proliferation and biases the differentiation of precursor cells into type I and type II cells ${ }^{16}$. By contrast, proliferation is greatly diminished upon deletion of $\beta$-catenin ${ }^{23,24}$ or the Wnt ligand Wnt $10 \mathrm{a}^{24}$, which in turn leads to loss of differentiated taste cells and diminished taste perception in mice. Here, we found Ctnnb1, Lef1, Tcf7 and Lgr5 expression are highly regulated during and after fractionated IR, but expression of each gene is not necessarily tightly linked and may depend on the discrete roles that each may play to maintain taste bud homeostasis. For example, the function of LEF and TCF transcription factors is highly dependent on the tissue type, isoforms, post-translational modifications, and interactions with co-activators and co-repressors (for reviews, $\operatorname{se}^{70,115,116}$ ). In the non-taste filiform papilla of the anterior tongue, LEF1-mediated transcription promotes proliferation and self-renewal of progenitors, while TCF4 mediates differentiation of filiform keratinocytes ${ }^{24}$. Here we find that downregulation of Lef1 parallels reduced proliferation in both AT and CVP, while both Lef1 and Tcf7 upregulation in the AT correlates with recovery of Type I and II cell marker expression. These observations suggest that in AT taste bud homeostasis, LEF1 regulates Wnt target genes that control progenitor proliferation, while LEF1 and TCF7 together may regulate taste cell differentiation. 
However, the molecular programs by which lingual progenitor daughter cells are directed to a non-taste versus taste cell fate remain undetermined.

Noticeably, in the AT Tcf7 expression is not as strongly downregulated as is Lef1, and Tcf7 expression is virtually unchanged in the CVP. However, downregulation of Tcf7 expression in irradiated epithelium may be masked by infiltration of $\mathrm{TCF}^{+}{ }^{+}$immune cells in response to irradiation-induced inflammation ${ }^{117}$. We have shown previously that TCF7, but not LEF1, is highly expressed by lymphocytes in the lamina propria in close proximity to the CVP epithelium of control mice ${ }^{23}$. Therefore, we cannot rule out that radiation-triggered infiltration of the taste epithelium by $\mathrm{TCF}^{+}$immune cells enhanced Tcf7 levels.

Leveraging Wnt/ $\beta$-catenin signaling to mitigate radiotherapy-induced taste loss. Our data prompt the suggestion that temporally and spatially precise activation of the Wnt $/ \beta$-catenin pathway could be used to mitigate radiation damage to taste bud homeostasis. Because Wnt signaling is downregulated coincident with reduced proliferation during fractionated IR, treatment with Wnt pathway activators may rescue proliferation, and subsequently the defect in taste cell renewal. Such an approach has been tested in preclinical mouse experiments to protect oral tissues from radiation injury or promote tissue repair. For example, genetic activation of Wnt 1 prevents radiation-induced salivary gland functional impairment ${ }^{28}$, R-spondin 1 , a secreted factor that promotes Wnt pathway activity, can prevent radiation-induced mucositis ${ }^{31}$ and administration of small molecule GSK3 antagonists supports tooth repair ${ }^{33}$. However, broadly activating the Wnt pathway in parallel with radiotherapy for head and neck cancer may prove detrimental as this approach may trigger tumor resistance or growth ${ }^{118}$. Thus, it is essential to adopt a Wnt activation approach that prevents tumor growth in xenograft head and neck irradiation models ${ }^{31,104}$, such as precise topical and transient delivery of a Wnt pathway activator (for instance as performed with GSK antagonists ${ }^{33}$, Smad7 $7^{104,119}$ and $\mathrm{KGF}^{63,107}$ ). In addition, targeting elements of the Wnt/ $\beta$-catenin pathway that are expressed more restrictively in taste tissues but not in cancer cells could potentially lower the risk of tumor growth ${ }^{120}$. Finally, identification of other pathways associated with proliferation reduction and recovery during and after fractionated irradiation, respectively, will highlight new potential therapeutic targets to lessen or prevent taste loss in head and neck cancer patients.

\section{Materials and Methods}

Ethics statement. All animal procedures were performed in an AAALAC-accredited facility in compliance with the Guide for the Care and Use of Laboratory Animals, Animal Welfare Act and Public Health Service Policy, and were approved by the Institutional Animal Care and Use Committee at the University of Colorado Anschutz Medical Campus.

Animals and procedures. Mice were housed in sterile ventilated cages with ad libitum access to irradiated diet and hyperchlorinated reverse osmosis water delivered via an automatic watering system. The light cycle was from 6:00 to 20:00. All mice were on a mixed background (FVB, 129 Sv, C57Bl6). Both males and females between $8-12$ weeks of age were used.

Irradiation. Mice were irradiated with $4 \mathrm{~Gy}$ daily for 5 consecutive days (IR Day 1-5) between 8:30 and 9:30 am in a Rad Source RS2000 X-ray irradiator ( 1.25 Gy/min, $160 \mathrm{kV}, 25 \mathrm{~mA})$. Control and irradiated mice were anesthetized with $300 \mathrm{mg} / \mathrm{kg}$ body weight Avertin (2,2,2-Tribromoethanol). Control mice were left in their cages, while irradiated mice were placed in a $50 \mathrm{ml}$ conical tube with the tip cut to allow adequate breathing, empty space filled with cotton, and a lead shield wrapped around the tube to cover the body except the head and neck. Irradiated mice were then returned to their cages to recover from anesthesia. Per IACUC regulation, mice losing more than $15 \%$ of their initial body weight (prior to IR on Day 1) were removed from the experiments and euthanized.

Tissue collection. For immunohistochemistry, mice were first anesthetized by i.p. injection of $300 \mathrm{mg} / \mathrm{kg}$ body weight Avertin (2,2,2-Tribromoethanol). Ice-cold normal saline was perfused transcardially prior to perfusion with periodate-lysine-paraformaldehyde (PLP) fixative (75 mM L-lysine monochloride, $1.6 \%$ formaldehyde, $10 \mathrm{mM}$ sodium periodate $)^{121,122}$. Tongues were then immersed in PLP fixative for $3 \mathrm{~h}$ at $4{ }^{\circ} \mathrm{C}$ on a rocker and transferred to $20 \%$ sucrose in $0.1 \mathrm{M}$ phosphate buffer (PB) overnight at $4^{\circ} \mathrm{C}$ under constant gentle rocking. Samples were embedded in O.C.T. Compound (Tissue-Tek 4583, Sakura Finetek, Torrance CA, USA), frozen on dry ice and stored at $-80^{\circ} \mathrm{C}$.

For qRT-PCR, mice were euthanized by $\mathrm{CO}_{2}$ inhalation followed by cervical dislocation. Tongues were collected and rinsed in ice-cold Normal Tyrode solution (140 mM NaCl, $5 \mathrm{mM} \mathrm{KCl,} 10 \mathrm{mM} \mathrm{HEPES}, 4 \mathrm{mM} \mathrm{CaCl}_{2}$, $10 \mathrm{mM}$ glucose, $1 \mathrm{mM} \mathrm{MgCl}, 1 \mathrm{mM}$ sodium pyruvate, $\mathrm{pH}$ 7.4). CVP epithelium was harvested by peeling after enzymatic digestion (Dispase II $3 \mathrm{mg} / \mathrm{ml}$ + Collagenase II $1 \mathrm{mg} / \mathrm{ml}$ in Normal Tyrode solution injected underneath the epithelium ${ }^{16}$ ) for 31 minutes at room temperature in calcium-free Tyrode. Harvested tissues were immediately placed in a cold tube on dry ice. Samples were stored at $-80^{\circ} \mathrm{C}$.

Immunohistochemistry. Immunostaining followed previously described procedures ${ }^{16,22}$. Frozen $12 \mu \mathrm{m}$ cryostat sections were collected on Superfrost Plus Slides (Fisher Scientific, Pittsburgh PA, USA). Primary and secondary antisera, amplification systems, and dilutions are listed in Table 1. Immunoreactivity for each antigen was absent when primary antibodies were omitted.

PLC 32 , 5-HT, KCNQ1. Double immunohistochemistry was performed as previously described ${ }^{16}$. Here, PLC32 or 5-HT rabbit antisera were used for double labeling with goat anti-KCNQ1 on PLP fixed sections. For 5-HT staining, 5-Hydroxy-L-tryptophan (Sigma-Aldrich H9772; $80 \mathrm{mg} / \mathrm{kg}, 6.4 \mathrm{mg} / \mathrm{ml}$ in 0.1 M PB, pH 7.4) was injected i.p. $1 \mathrm{~h}$ before fixation ${ }^{58}$. Sections were thawed at room temperature, rehydrated in $1 \mathrm{X}$ phosphate buffered 


\begin{tabular}{|c|c|c|c|c|c|c|}
\hline & Primary antibody & Source Reference \#/RRID \# & Dilution & Secondary Antibody & Source Reference \#/RRID \# & Dilution \\
\hline \multirow{2}{*}{ Taste Cell Markers } & $\begin{array}{l}\text { Rabbit } \\
\text { anti-PLC } \beta 2\end{array}$ & $\begin{array}{l}\text { Santa Cruz } \\
\text { sc-206/AB_632197 }\end{array}$ & $1 / 1000$ & \multirow{2}{*}{$\begin{array}{l}\text { Alexa Fluor }{ }^{\circledR} 488 \text { donkey } \\
\text { anti-rabbit IgG }\end{array}$} & \multirow{2}{*}{$\begin{array}{l}\text { ThermoFisher Scientific } \\
A 11008 / A B \_143165\end{array}$} & \multirow{2}{*}{$1 / 1000$} \\
\hline & $\begin{array}{l}\text { Rabbit } \\
\text { anti-5HT }\end{array}$ & $\begin{array}{l}\text { Immunostar } \\
\text { 20080/AB_572263 }\end{array}$ & $1 / 500$ & & & \\
\hline \multirow[t]{2}{*}{ Taste Bud Marker } & Goat anti-KCNQ1 & $\begin{array}{l}\text { Santa Cruz } \\
\text { sc-10646/AB_2131554 }\end{array}$ & $\begin{array}{l}\text { CVP } 1 / 500 \\
\text { AT: } 1 / 250\end{array}$ & $\begin{array}{l}\text { Alexa Fluor }^{\circledR} 488 \text { or } 546 \\
\text { donkey anti-goat IgG }\end{array}$ & $\begin{array}{l}\text { ThermoFisher Scientific } \\
\text { A11055/AB_2534102 } \\
\text { A11056/AB_142628 }\end{array}$ & $1 / 1000$ \\
\hline & Rat anti-Krt8 & $\begin{array}{l}\text { Developmental Studies Hybridoma Bank } \\
\text { TROMA-I/AB_531826 }\end{array}$ & $1 / 250$ & $\begin{array}{l}\text { Alexa Fluor }{ }^{\circledR} 647 \text { goat } \\
\text { anti-rat IgG }\end{array}$ & $\begin{array}{l}\text { ThermoFisher Scientific } \\
A 11006 / A B \_2534074\end{array}$ & $1 / 1000$ \\
\hline Progenitor marker & Rabbit anti-Krt5 & $\begin{array}{l}\text { Abcam } \\
\text { ab53121/AB_869889 }\end{array}$ & $1 / 500$ & $\begin{array}{l}\text { Alexa Fluor }{ }^{\circledR} 647 \text { goat } \\
\text { anti-rabbit IgG }\end{array}$ & $\begin{array}{l}\text { ThermoFisher Scientific } \\
\text { A21245/AB_2535813 }\end{array}$ & $1 / 1000$ \\
\hline Basement membrane & Mouse anti-Ecadherin & $\begin{array}{l}\text { Developmental Studies Hybridoma Bank } \\
\text { 5D3/AB_528116 }\end{array}$ & $1 / 100$ & $\begin{array}{l}\text { Alexa Fluor }{ }^{\circledR} 555 \text { goat } \\
\text { anti-mouse IgG2a }\end{array}$ & $\begin{array}{l}\text { ThermoFisher Scientific } \\
A 21137 / A B \_2535776\end{array}$ & $1 / 1000$ \\
\hline \multirow{2}{*}{ Proliferation Marker } & \multirow{2}{*}{ Rabbit anti-Ki67 } & \multirow{2}{*}{$\begin{array}{l}\text { Thermo Scientific } \\
R M-9106-S / A B \_2341197\end{array}$} & \multirow[b]{2}{*}{$1 / 200$} & $\begin{array}{l}\text { Goat anti-rabbit IgG } \\
\text { biotinylated }\end{array}$ & $\begin{array}{l}\text { Vector Labs } \\
P K-6101 / A B \_2336820\end{array}$ & $1 / 500$ \\
\hline & & & & $\begin{array}{l}\text { Streptavidin Alexa Fluor }{ }^{\circledR} \\
488 \text { conjugate }\end{array}$ & $\begin{array}{l}\text { ThermoFisher Scientific } \\
\text { S11223/AB_2336881 }\end{array}$ & $1 / 1000$ \\
\hline \multirow{2}{*}{ Apoptosis } & \multirow{2}{*}{ Rabbit anti-Cleaved Caspase3 } & \multirow{2}{*}{$\begin{array}{l}\text { Cell Signaling Technology } \\
\text { 9664/AB_2070042 }\end{array}$} & \multirow{2}{*}{$1 / 250$} & $\begin{array}{l}\text { Donkey anti-rabbit IgG } \\
\text { biotinylated }\end{array}$ & $\begin{array}{l}\text { ThermoFisher Scientific } \\
\text { 65-6140/AB_2533969 }\end{array}$ & $1 / 250$ \\
\hline & & & & $\begin{array}{l}\text { Streptavidin Alexa Fluor }{ }^{\circledR} \\
546 \text { conjugate }\end{array}$ & $\begin{array}{l}\text { ThermoFisher Scientific } \\
\text { S11225/AB_2532130 }\end{array}$ & $1 / 1000$ \\
\hline
\end{tabular}

Table 1. Primary and secondary antibodies used for immunohistochemistry.

saline (PBS), incubated for $1.5 \mathrm{~h}$ at room temperature in blocking solution ( $5 \%$ normal donkey serum, $1 \%$ bovine serum albumin, $0.3 \%$ Triton X100 in $1 \mathrm{X}$ PBS pH 7.3), and incubated with primary antisera diluted in blocking solution overnight at $4^{\circ} \mathrm{C}$. Sections were thoroughly washed in $1 \mathrm{X}$ PBS $+0.1 \%$ Triton X100, and incubated with secondary antisera diluted in blocking solution for $1 \mathrm{~h}$ at room temperature and protected from light. Sections were counterstained with DAPI diluted $1 / 60,000$ in $0.1 \mathrm{M} \mathrm{PB}$ for $3 \mathrm{~min}$ at room temperature, and coverslipped with Fluoromount G.

Ki67/Krt8/Ecadherin, Cleaved Caspase3/KCNQ1. Sections were thawed, rehydrated in 1X PBS, and antigen retrieval performed in $10 \mathrm{mM}$ sodium citrate $\mathrm{pH} 6+0.05 \%$ tween 20 at $95^{\circ} \mathrm{C}$ for $15 \mathrm{~min}$. After cooling to room temperature in antigen retrieval solution, sections were incubated in blocking solution (as above) for $1 \mathrm{~h}$ at room temperature, and incubated with Ki67, Krt8 and Ecadherin antisera or Cleaved Caspase3 and KCNQ1 antisera diluted in blocking solution overnight at $4^{\circ} \mathrm{C}$. Sections were washed in $1 \mathrm{X}$ PBS, and blocking of endogenous avidin/biotin was performed as above. Sections were incubated with anti-rabbit biotin-conjugated antibody diluted in $1 \mathrm{X}$ PBS $+0.1 \%$ tween $20+2.5 \%$ normal goat serum (donkey serum for Caspase $3 /$ KCNQ1 staining) for $1 \mathrm{~h}$ at room temperature. Streptavidin-Alexa 488, goat anti-rabbit Alexa 647 and goat anti-mouse IgG2a Alexa 555 (for detection of Ki67, Krt8 and Ecadherin, respectively) or Streptavidin-Alexa 546 and donkey anti-goat Alexa 488 (for detection of Caspase 3 and KCNQ1, respectively) were diluted in $1 \%$ bovine serum albumin $+0.3 \%$ Triton X100 in 1X PBS and then applied to the sections for $1 \mathrm{~h}$ at room temperature. Sections were counterstained with DAPI diluted 1/60,000 in $0.1 \mathrm{M} \mathrm{PB} \mathrm{pH} 7.2$ for $3 \mathrm{~min}$ at room temperature, washed, and coverslipped using Fluoromount G.

TUNEL. To assess cell death, the In Situ Cell Death Detection Kit TMR red (Roche Applied Science, Cat $\# 12156792910$ ) was used. Sections were thawed at room temperature, rehydrated in 1X PBS prior to antigen retrieval in $0.1 \mathrm{M}$ Sodium Citrate $\mathrm{pH} 6$ for $15 \mathrm{~min}$ at $90^{\circ} \mathrm{C}$. Sections were washed and incubated in permeabilization solution $(0.1 \%$ Triton X100 in $0.1 \%$ Sodium citrate) for 2 min on ice. Slides were washed and incubated in blocking buffer ( $50 \mathrm{mM}$ Tris- $\mathrm{HCl} \mathrm{pH}=7.5,3 \% \mathrm{BSA}, 20 \%$ normal donkey serum) $30 \mathrm{~min}$ at room temperature. TUNEL reaction was performed according to the manufacturer's instructions, by mixing 1 volume of Enzyme Solution with 9 volumes of Label Solution and incubating sections $60 \mathrm{~min}$ at $37^{\circ} \mathrm{C}$ in a humidified chamber. One negative control was included by incubating a slide with Label Solution only, and one positive control was added

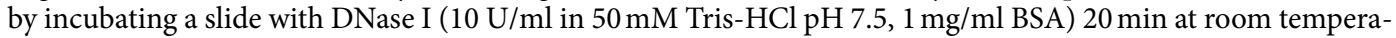
ture prior to the TUNEL reaction. Sections were washed, and incubated for $1 \mathrm{~h}$ at room temperature in blocking solution (5\% normal donkey serum, $1 \%$ bovine serum albumin, $0.3 \%$ Triton X100 in 1X PBS pH 7.3), and incubated with Krt5 and KCNQ1 primary antisera diluted in blocking solution overnight at $4{ }^{\circ} \mathrm{C}$. Sections were thoroughly washed in $1 \mathrm{X}$ PBS $+0.1 \%$ Triton X100, and incubated with secondary antisera diluted in blocking solution for $1 \mathrm{~h}$ at room temperature. Sections were counterstained with DAPI diluted 1/60,000 in $0.1 \mathrm{M}$ PB for 3 min at room temperature, washed, and slides mounted with Prolong Gold (ThermoFisher Scientific).

Image acquisition and analysis. Confocal fluorescence images were acquired using a Nikon A1R laser-scanning confocal Ti2 microscope and NIS Elements software driving a Nikon motorized Ti2-E. VEG images were acquired using a Leica TCS SP8 laser-scanning confocal microscope and LAS X software driving a Dmi8 motorized microscope stand. Immunolabeled cells were tallied by analyzing both $0.75 \mu \mathrm{m}$ optical sections and compressed z-stacks of 14 optical sections. All sections of the CVP, except the first and last sections with incomplete trenches, were analyzed. Anterior tongue was cut as $12 \mu \mathrm{m}$ serial sections in 6 sets such that sections 


\begin{tabular}{|c|c|c|c|c|}
\hline Gene name & Refseq & Forward primer $\left(5^{\prime}-3^{\prime}\right)$ & Reverse primer $\left(5^{\prime}-3^{\prime}\right)$ & Source \\
\hline Ctnnb1/ $\beta$-catenin & NM_001165902 & CCCAGTCCTTCACGCAAGAG & CATCTAGCGTCTCAGGGAACA & \# \\
\hline Entpd2/Ntpdase2 & NM_009849.2 & GACAAGGAAAATGACACAGGTATCGTGG & GTTCAAGACATTCAACCAGACTC & 124 \\
\hline Lef1 & NM_010703 & TATGAACAGCGACCCGTACA & CTCGTCGCTGTAGGTGATGA & ${ }^{*}$ \\
\hline Lgr5 & NM_010195 & CAGCGTCTTCACCTCCTACC & CCTTGGGAATGTGTGTCAAA & "* \\
\hline Mki67/Ki67 & NM_001081117 & CTGCCTCAGATGGCTCAAAGA & GAAGACTTCGGTTCCCTGTAAC & 125 \\
\hline$P l c b 2 / P l c \beta 2$ & NM_177568.2 & GAGCAAATCGCCAAGATGAT & CCTTGTCTGTGGTGACCTTG & 124 \\
\hline Pmaip1/Noxa & NM_021451 & AGGAAGGAAGTTCCGCCG & AGCGTTTCTCTCATCACATCACA & 126 \\
\hline Rpl19 & NM_009078.2 & GGTCTGGTTGGATCCCAATG & CCCGGGAATGGACAGTCA & 127 \\
\hline Snap25 & NM_011428 & ATCCGCAGGGTAACAAATGATG & CGGAGGTTTCCGATGATGC & $\#$ \\
\hline$T c f 7$ & NM_009331 & CAATCTGCTCATGCCCTACC & TAGAGTGGAGAAAGCTGGGG & * \\
\hline
\end{tabular}

Table 2. Primers sequences used in Real-Time RT-PCR. "https://pga.mgh.harvard.edu/primerbank/index. html. *http://mouseprimerdepot.nci.nih.gov.

on each slide were separated by $72 \mu \mathrm{m}$. FFP were analyzed in the $2^{\text {nd }}$ through the $12^{\text {th }}$ section, a region representing $648 \mu \mathrm{m}$ of the anterior tongue starting $\sim 72 \mu \mathrm{m}$ from the tongue tip.

Proliferative index in the CVP was calculated as previously ${ }^{16,17}$. The number of Ki67 ${ }^{+}$basal cells was divided by the number of $\mathrm{DAPI}^{+}$basal cells along the basement membrane within the portion of the CVP trenches housing taste buds. Taste bud size was measured by using the NIS Elements Analysis software. Each KCNQ1 $1^{+}$taste bud profile was outlined with the Polygon selection tool to measure taste bud area (Area in $\mu \mathrm{m}^{2}$ ) and the Equivalent diameter in $\mu \mathrm{m}$ calculated (Eqdiameter $=\sqrt{4 \times \mathrm{Area} / \pi}$ ). Taste buds were counted using the Count tool. When the size of a counted structure was significantly different in control versus irradiated mice, Abercrombie correction $^{38}$ was applied $\left(P=A \frac{M}{L+M}\right.$; P corrected count, A crude count, $\mathrm{M}$ section thickness $-12 \mu \mathrm{m}, \mathrm{L}$ structure size $-\mathrm{Ki}^{+} 7^{+}, \mathrm{PLC} \beta 2^{+}$, or $5-\mathrm{H}^{\mathrm{L}}{ }^{+}$nuclear width, or taste bud Eqdiameter). The size of 20 nuclei, when applicable, of each cell population was measured on five $0.75 \mu \mathrm{m}$ optical sections using the NIS Elements Analysis software, and averaged. Each correction factor was calculated and applied specifically for each animal.

Real-Time RT-PCR. Total RNA was extracted using an RNeasy Plus Micro kit (Qiagen, 74034), and RNA quantity measure by Nanodrop (ThermoFisher Scientific). cDNA was synthesized from $400 \mathrm{ng}$ total CVP RNA or 1000 ng AT RNA using iScript cDNA Synthesis Kit (Biorad) according to manufacturer's protocol. cDNA equivalent of $2.5 \mathrm{ng}$ total RNA, and $200 \mathrm{nM}$ of the forward and reverse primers were mixed with Power SYBR Green PCR Master Mix (Applied Biosystems). Real-Time PCR was run in a StepOnePlus Real-Time thermocycler (Applied Biosystems) and consisted of forty $95^{\circ} \mathrm{C} / 15 \mathrm{~s}-60^{\circ} \mathrm{C} / 60 \mathrm{~s}$ cycles. The comparative $\Delta \Delta \mathrm{Ct}$ method was used for relative quantification of gene expression ${ }^{123}$. mRNA levels were normalized to Rpl19 mRNA levels. Expression of a gene of interest in irradiated tissues was relative to its expression in control tissues. Primers sequences are in Table 2 .

Statistical analyses. were performed with SigmaStat (Systat Software, San Jose, CA, USA) or Graphpad Prism (San Diego, CA, USA). Normal distribution and equal variances between groups were assessed to determine whether to run a parametric or non-parametric test. A Mann-Whitney test or Student's t-test was run to determine statistical differences established with a minimum confidence interval of $95 \%$. qPCR data were plotted with controls from all time points pooled after assessing that they were not statistically different (ANOVA and ANOVA on ranks for parametric and non-parametric data, respectively). Non-parametric data are represented as medians, $1^{\text {st }}$ and $3^{\text {rd }}$ quartiles with data distribution (violin plot), while parametric data are represented as scatter plots (individual symbols) with means \pm SEM.

\section{Data availability}

All relevant data are within the paper and its supporting information files.

Received: 21 August 2019; Accepted: 10 November 2019;

Published online: 29 November 2019

\section{References}

1. Siegel, R. L., Miller, K. D. \& Jemal, A. Cancer Statistics, 2017. CA Cancer J Clin 67, 7-30, https://doi.org/10.3322/caac.21387 (2017).

2. Deloch, L. et al. Modern Radiotherapy Concepts and the Impact of Radiation on Immune Activation. Front Oncol 6, 141, https:// doi.org/10.3389/fonc.2016.00141 (2016).

3. Bolze, M. S., Fosmire, G. J., Stryker, J. A., Chung, C. K. \& Flipse, B. G. Taste acuity, plasma zinc levels, and weight loss during radiotherapy: a study of relationships. Radiology 144, 163-169, https://doi.org/10.1148/radiology.144.1.7089250 (1982).

4. Chencharick, J. D. \& Mossman, K. L. Nutritional consequences of the radiotherapy of head and neck cancer. Cancer 51, 811-815, doi:10.1002/1097-0142(19830301)51:5<811::aid-cncr2820510511>3.0.co;2-m (1983).

5. Nelson, G. M. Biology of taste buds and the clinical problem of taste loss. The Anatomical record 253, 70-78, doi:10.1002/ (SICI) 1097-0185(199806)253:3<70::AID-AR3>3.0.CO;2-I (1998).

6. Ray-Chaudhuri, A., Shah, K. \& Porter, R. J. The oral management of patients who have received radiotherapy to the head and neck region. Br Dent J 214, 387-393, https://doi.org/10.1038/sj.bdj.2013.380 (2013).

7. Deshpande, T. S. et al. Radiation-Related Alterations of Taste Function in Patients With Head and Neck Cancer: a Systematic Review. Curr Treat Options Oncol 19, 72, https://doi.org/10.1007/s11864-018-0580-7 (2018). 
8. Mahdavi, R., Faramarzi, E., Mohammad-Zadeh, M., Ghaeammaghami, J. \& Jabbari, M. V. Consequences of radiotherapy on nutritional status, dietary intake, serum zinc and copper levels in patients with gastrointestinal tract and head and neck cancer. Saudi Med J 28, 435-440 (2007).

9. Ogama, N. et al. Appetite and adverse effects associated with radiation therapy in patients with head and neck cancer. Eur J Oncol Nurs 14, 3-10, https://doi.org/10.1016/j.ejon.2009.07.004 (2010).

10. Hutton, J. L., Baracos, V. E. \& Wismer, W. V. Chemosensory dysfunction is a primary factor in the evolution of declining nutritional status and quality of life in patients with advanced cancer. J Pain Symptom Manage 33, 156-165, https://doi.org/10.1016/j. jpainsymman.2006.07.017 (2007).

11. Ruo Redda, M. G. \& Allis, S. Radiotherapy-induced taste impairment. Cancer Treat Rev 32, 541-547, https://doi.org/10.1016/j. ctrv.2006.06.003 (2006).

12. Ravasco, P., Monteiro-Grillo, I., Marques Vidal, P. \& Camilo, M. E. Impact of nutrition on outcome: a prospective randomized controlled trial in patients with head and neck cancer undergoing radiotherapy. Head Neck 27, 659-668, https://doi.org/10.1002/ hed.20221 (2005).

13. Leventhal, E. M. Post-Radiation Mouth Blindness. The Lancet 274, 1138-1139, https://doi.org/10.1016/s0140-6736(59)90117-5 (1959).

14. Maes, A. et al. De Gustibus: time scale of loss and recovery of tastes caused by radiotherapy. Radiother Oncol 63, 195-201, https:// doi.org/10.1016/s0167-8140(02)00025-7 (2002).

15. Okubo, T., Clark, C. \& Hogan, B. L. Cell lineage mapping of taste bud cells and keratinocytes in the mouse tongue and soft palate. Stem cells (Dayton, Ohio) 27, 442-450, https://doi.org/10.1634/stemcells.2008-0611 (2009).

16. Gaillard, D., Xu, M., Liu, F., Millar, S. E. \& Barlow, L. A. beta-Catenin Signaling Biases Multipotent Lingual Epithelial Progenitors to Differentiate and Acquire Specific Taste Cell Fates. PLoS genetics 11, e1005208, https://doi.org/10.1371/journal.pgen.1005208 (2015).

17. Nguyen, H. M., Reyland, M. E. \& Barlow, L. A. Mechanisms of taste bud cell loss after head and neck irradiation. J Neurosci 32, 3474-3484, https://doi.org/10.1523/JNEUROSCI.4167-11.2012 (2012).

18. Jewkes, B. C., Barlow, L. A. \& Delay, E. R. Effect of Radiation on Sucrose Detection Thresholds of Mice. Chemical senses 43, 53-58, https://doi.org/10.1093/chemse/bjx066 (2017).

19. Irune, E., Dwivedi, R. C., Nutting, C. M. \& Harrington, K. J. Treatment-related dysgeusia in head and neck cancer patients. Cancer Treat Rev 40, 1106-1117, https://doi.org/10.1016/j.ctrv.2014.06.011 (2014).

20. Rathod, S., Livergant, J., Klein, J., Witterick, I. \& Ringash, J. A systematic review of quality of life in head and neck cancer treated with surgery with or without adjuvant treatment. Oral oncology 51, 888-900, https://doi.org/10.1016/j.oraloncology.2015.07.002 (2015).

21. Nusse, R. \& Clevers, H. Wnt/beta-Catenin Signaling, Disease, and Emerging Therapeutic Modalities. Cell 169, 985-999, https:// doi.org/10.1016/j.cell.2017.05.016 (2017)

22. Gaillard, D. \& Barlow, L. A. Taste bud cells of adult mice are responsive to Wnt/beta-catenin signaling: implications for the renewal of mature taste cells. Genesis 49, 295-306, https://doi.org/10.1002/dvg.20731 (2011).

23. Gaillard, D. et al. beta-catenin is required for taste bud cell renewal and behavioral taste perception in adult mice. PLoS genetics 13, e1006990, https://doi.org/10.1371/journal.pgen.1006990 (2017).

24. Xu, M. et al. WNT10A mutation causes ectodermal dysplasia by impairing progenitor cell proliferation and KLF4-mediated differentiation. Nature communications 8, 15397, https://doi.org/10.1038/ncomms15397 (2017).

25. Suzuki, Y., Tsunekawa, H., Obara, N., Irie, K. \& Shibata, S. Expression and activation of $\beta$-catenin in developing and denervated taste buds. 北海道医療大学歯学雑誌 = The dental journal of Health Sciences University of Hokkaido 31, 63-72 (2012).

26. Suh, H. N. et al. Quiescence Exit of Tert(+) Stem Cells by Wnt/beta-Catenin Is Indispensable for Intestinal Regeneration. Cell Rep 21, 2571-2584, https://doi.org/10.1016/j.celrep.2017.10.118 (2017).

27. Gong, W. et al. Mesenchymal stem cells stimulate intestinal stem cells to repair radiation-induced intestinal injury. Cell Death Dis 7, e2387, https://doi.org/10.1038/cddis.2016.276 (2016).

28. Hai, B. et al. Concurrent transient activation of Wnt/beta-catenin pathway prevents radiation damage to salivary glands. International journal of radiation oncology, biology, physics 83, e109-116, https://doi.org/10.1016/j.ijrobp.2011.11.062 (2012).

29. Chandra, A. et al. Suppression of Sclerostin Alleviates Radiation-Induced Bone Loss by Protecting Bone-Forming Cells and Their Progenitors Through Distinct Mechanisms. J Bone Miner Res 32, 360-372, https://doi.org/10.1002/jbmr.2996 (2017).

30. Hai, B. et al. Wnt/beta-catenin signaling regulates postnatal development and regeneration of the salivary gland. Stem cells and development 19, 1793-1801, https://doi.org/10.1089/scd.2009.0499 (2010).

31. Zhao, J. et al. R-Spondin1 protects mice from chemotherapy or radiation-induced oral mucositis through the canonical Wnt/betacatenin pathway. Proc Natl Acad Sci USA 106, 2331-2336, https://doi.org/10.1073/pnas.0805159106 (2009).

32. Lento, W. et al. Loss of beta-catenin triggers oxidative stress and impairs hematopoietic regeneration. Genes Dev 28, 995-1004, https://doi.org/10.1101/gad.231944.113 (2014)

33. Neves, V. C., Babb, R., Chandrasekaran, D. \& Sharpe, P. T. Promotion of natural tooth repair by small molecule GSK3 antagonists. Sci Rep 7, 39654, https://doi.org/10.1038/srep39654 (2017).

34. Thotala, D. K., Hallahan, D. E. \& Yazlovitskaya, E. M. Glycogen synthase kinase 3beta inhibitors protect hippocampal neurons from radiation-induced apoptosis by regulating MDM2-p53 pathway. Cell Death Differ 19, 387-396, https://doi.org/10.1038/ cdd.2011.94 (2012)

35. Dorr, W., Emmendorfer, H. \& Weber-Frisch, M. Tissue kinetics in mouse tongue mucosa during daily fractionated radiotherapy. Cell proliferation 29, 495-504, https://doi.org/10.1111/j.1365-2184.1996.tb00992.x (1996).

36. Wie, S. M., Wellberg, E., Karam, S. D. \& Reyland, M. E. Tyrosine Kinase Inhibitors Protect the Salivary Gland from Radiation Damage by Inhibiting Activation of Protein Kinase C-delta. Mol Cancer Ther 16, 1989-1998, https://doi.org/10.1158/1535-7163. MCT-17-0267 (2017).

37. Wang, H. et al. Expression of the voltage-gated potassium channel KCNQ1 in mammalian taste bud cells and the effect of its nullmutation on taste preferences. The Journal of comparative neurology 512,384-398, https://doi.org/10.1002/cne.21899 (2009).

38. Abercrombie, M. Estimation of nuclear population from microtome sections. The Anatomical record 94, 239-247, https://doi. org/10.1002/ar.1090940210 (1946).

39. Bartel, D. L., Sullivan, S. L., Lavoie, E. G., Sevigny, J. \& Finger, T. E. Nucleoside triphosphate diphosphohydrolase-2 is the ectoATPase of type I cells in taste buds. The Journal of comparative neurology 497, 1-12, https://doi.org/10.1002/cne.20954 (2006).

40. Lawton, D. M., Furness, D. N., Lindemann, B. \& Hackney, C. M. Localization of the glutamate-aspartate transporter, GLAST, in rat taste buds. The European journal of neuroscience 12, 3163-3171, https://doi.org/10.1046/j.1460-9568.2000.00207.x (2000).

41. Pumplin, D. W., Yu, C. \& Smith, D. V. Light and dark cells of rat vallate taste buds are morphologically distinct cell types. The Journal of comparative neurology 378, 389-410, doi:10.1002/(sici)1096-9861(19970217)378:3<389::aid-cne7>3.0.co;2-\# (1997).

42. Kim, M. R. et al. Regional expression patterns of taste receptors and gustducin in the mouse tongue. Biochem Biophys Res Commun 312, 500-506, https://doi.org/10.1016/j.bbrc.2003.10.137 (2003).

43. Adler, E. et al. A novel family of mammalian taste receptors. Cell 100, 693-702, https://doi.org/10.1016/s0092-8674(00)80705-9 (2000).

44. Clapp, T. R., Stone, L. M., Margolskee, R. F. \& Kinnamon, S. C. Immunocytochemical evidence for co-expression of Type III IP3 receptor with signaling components of bitter taste transduction. BMC Neurosci 2, 6 (2001). 
45. Nelson, G. et al. Mammalian sweet taste receptors. Cell 106, 381-390, https://doi.org/10.1016/s0092-8674(01)00451-2 (2001).

46. Zhang, Y. et al. Coding of sweet, bitter, and umami tastes: different receptor cells sharing similar signaling pathways. Cell 112, 293-301, https://doi.org/10.1016/s0092-8674(03)00071-0 (2003).

47. Oka, Y., Butnaru, M., von Buchholtz, L., Ryba, N. J. \& Zuker, C. S. High salt recruits aversive taste pathways. Nature 494, 472-475, https://doi.org/10.1038/nature11905 (2013).

48. Huang, A. L. et al. The cells and logic for mammalian sour taste detection. Nature 442, 934-938, https://doi.org/10.1038/ nature05084 (2006).

49. Huang, Y. A., Maruyama, Y., Stimac, R. \& Roper, S. D. Presynaptic (Type III) cells in mouse taste buds sense sour (acid) taste. J Physiol 586, 2903-2912, https://doi.org/10.1113/jphysiol.2008.151233 (2008).

50. Kataoka, S. et al. The candidate sour taste receptor, PKD2L1, is expressed by type III taste cells in the mouse. Chemical senses 33, 243-254, https://doi.org/10.1093/chemse/bjm083 (2008).

51. Lewandowski, B. C., Sukumaran, S. K., Margolskee, R. F. \& Bachmanov, A. A. Amiloride-Insensitive Salt Taste Is Mediated by Two Populations of Type III Taste Cells with Distinct Transduction Mechanisms. J Neurosci 36, 1942-1953, https://doi.org/10.1523/ JNEUROSCI.2947-15.2016 (2016).

52. Ma, H., Yang, R., Thomas, S. M. \& Kinnamon, J. C. Qualitative and quantitative differences between taste buds of the rat and mouse. BMC Neurosci 8, 5, https://doi.org/10.1186/1471-2202-8-5 (2007).

53. Ohtubo, Y. \& Yoshii, K. Quantitative analysis of taste bud cell numbers in fungiform and soft palate taste buds of mice. Brain Res 1367, 13-21, https://doi.org/10.1016/j.brainres.2010.10.060 (2011).

54. Wilson, C. E., Vandenbeuch, A. \& Kinnamon, S. C. Physiological and Behavioral Responses to Optogenetic Stimulation of PKD2L1(+) Type III Taste Cells. eNeuro 6, ENEURO.0107-0119.2019, https://doi.org/10.1523/ENEURO.0107-19.2019 (2019).

55. Clapp, T. R., Yang, R., Stoick, C. L., Kinnamon, S. C. \& Kinnamon, J. C. Morphologic characterization of rat taste receptor cells that express components of the phospholipase C signaling pathway. The Journal of comparative neurology 468, 311-321, https://doi. org/10.1002/cne.10963 (2004).

56. Yang, R., Crowley, H. H., Rock, M. E. \& Kinnamon, J. C. Taste cells with synapses in rat circumvallate papillae display SNAP-25-like immunoreactivity. The Journal of comparative neurology 424, 205-215, doi:10.1002/1096-9861(20000821)424:2<205::aidcne2>3.0.co; 2 -f (2000).

57. Miura, H., Scott, J. K., Harada, S. \& Barlow, L. A. Sonic hedgehog-expressing basal cells are general post-mitotic precursors of functional taste receptor cells. Dev Dyn 243, 1286-1297, https://doi.org/10.1002/dvdy.24121 (2014).

58. Yee, C. L., Yang, R., Bottger, B., Finger, T. E. \& Kinnamon, J. C. “Type III” cells of rat taste buds: immunohistochemical and ultrastructural studies of neuron-specific enolase, protein gene product 9.5, and serotonin. The Journal of comparative neurology 440, 97-108, https://doi.org/10.1002/cne.1372 (2001).

59. Endl, E. \& Gerdes, J. The Ki-67 protein: fascinating forms and an unknown function. Experimental cell research 257, 231-237, https://doi.org/10.1006/excr.2000.4888 (2000).

60. Gerdes, J. et al. Cell cycle analysis of a cell proliferation-associated human nuclear antigen defined by the monoclonal antibody Ki-67. J Immunol 133, 1710-1715 (1984).

61. Limesand, K. H. et al. Insulin-like growth factor-1 preserves salivary gland function after fractionated radiation. International journal of radiation oncology, biology, physics 78, 579-586, https://doi.org/10.1016/j.ijrobp.2010.03.035 (2010).

62. Bralic, M. et al. Cell death and cell proliferation in mouse submandibular gland during early post-irradiation phase. Acta Med Okayama 59, 153-159, https://doi.org/10.18926/AMO/31948 (2005).

63. Zheng, C. et al. Prevention of radiation-induced salivary hypofunction following hKGF gene delivery to murine submandibular glands. Clin Cancer Res 17, 2842-2851, https://doi.org/10.1158/1078-0432.CCR-10-2982 (2011).

64. Li, R. et al. Ionizing Radiation Blocks Hair Cell Regeneration in Zebrafish Lateral Line Neuromasts by Preventing Wnt Signaling. Mol Neurobiol 55, 1639-1651, https://doi.org/10.1007/s12035-017-0430-9 (2018).

65. Waksman, R. et al. Effect of intravascular irradiation on cell proliferation, apoptosis, and vascular remodeling after balloon overstretch injury of porcine coronary arteries. Circulation 96, 1944-1952, https://doi.org/10.1161/01.cir.96.6.1944 (1997)

66. Webster, M., Witkin, K. L. \& Cohen-Fix, O. Sizing up the nucleus: nuclear shape, size and nuclear-envelope assembly. J Cell Sci 122, 1477-1486, https://doi.org/10.1242/jcs.037333 (2009).

67. Pietsch, E. C., Sykes, S. M., McMahon, S. B. \& Murphy, M. E. The p53 family and programmed cell death. Oncogene 27, 6507-6521, https://doi.org/10.1038/onc.2008.315 (2008).

68. Porter, A. G. \& Janicke, R. U. Emerging roles of caspase-3 in apoptosis. Cell Death Differ 6, 99-104, https://doi.org/10.1038/ sj.cdd.4400476 (1999)

69. Mcllwain, D. R., Berger, T. \& Mak, T. W. Caspase functions in cell death and disease. Cold Spring Harbor perspectives in biology 5 , a008656, https://doi.org/10.1101/cshperspect.a008656 (2013).

70. Cadigan, K. M. \& Waterman, M. L. TCF/LEFs and Wnt signaling in the nucleus. Cold Spring Harbor perspectives in biology 4 , https://doi.org/10.1101/cshperspect.a007906 (2012).

71. Yee, K. K. et al. Lgr5-EGFP marks taste bud stem/progenitor cells in posterior tongue. Stem cells (Dayton, Ohio) 31, 992-1000, https://doi.org/10.1002/stem.1338 (2013).

72. Takeda, N. et al. Lgr5 Identifies Progenitor Cells Capable of Taste Bud Regeneration after Injury. PLoS One 8, e66314, https://doi. org/10.1371/journal.pone.0066314 (2013).

73. Glinka, A. et al. LGR4 and LGR5 are R-spondin receptors mediating Wnt/beta-catenin and Wnt/PCP signalling. EMBO reports 12, 1055-1061, https://doi.org/10.1038/embor.2011.175 (2011).

74. Ren, W. et al. Single Lgr5- or Lgr6-expressing taste stem/progenitor cells generate taste bud cells ex vivo. Proc Natl Acad Sci USA 111, 16401-16406, https://doi.org/10.1073/pnas.1409064111 (2014).

75. Bazalova, M. \& Graves, E. E. The importance of tissue segmentation for dose calculations for kilovoltage radiation therapy. Med Phys 38, 3039-3049, https://doi.org/10.1118/1.3589138 (2011).

76. Akar, A., Baltas, H., Çevik, U., Korkmaz Görür, F. \& Okumuşoğlu, N. Measurement of attenuation coefficients for bone, muscle, fat and water at 140, 364 and $662 \mathrm{keV}$-ray energies. Vol. 102 (2006).

77. de Jonge, M. E., Huitema, A. D., Rodenhuis, S. \& Beijnen, J. H. Clinical pharmacokinetics of cyclophosphamide. Clin Pharmacokinet 44, 1135-1164, https://doi.org/10.2165/00003088-200544110-00003 (2005).

78. Berteretche, M. V. et al. Decreased taste sensitivity in cancer patients under chemotherapy. Support Care Cancer 12, 571-576, https://doi.org/10.1007/s00520-004-0589-2 (2004).

79. Gamper, E. M. et al. Taste alterations in breast and gynaecological cancer patients receiving chemotherapy: prevalence, course of severity, and quality of life correlates. Acta Oncol 51, 490-496, https://doi.org/10.3109/0284186X.2011.633554 (2012).

80. Mukherjee, N., Pal Choudhuri, S., Delay, R. J. \& Delay, E. R. Cellular mechanisms of cyclophosphamide-induced taste loss in mice. PLoS One 12, e0185473, https://doi.org/10.1371/journal.pone.0185473 (2017).

81. Migden, M. R. et al. Treatment with two different doses of sonidegib in patients with locally advanced or metastatic basal cell carcinoma (BOLT): a multicentre, randomised, double-blind phase 2 trial. Lancet Oncol 16, 716-728, https://doi.org/10.1016/ S1470-2045(15)70100-2 (2015).

82. Rodon, J. et al. A phase I, multicenter, open-label, first-in-human, dose-escalation study of the oral smoothened inhibitor Sonidegib (LDE225) in patients with advanced solid tumors. Clin Cancer Res 20, 1900-1909, https://doi.org/10.1158/1078-0432. CCR-13-1710 (2014). 
83. Jain, S., Song, R. \& Xie, J. Sonidegib: mechanism of action, pharmacology, and clinical utility for advanced basal cell carcinomas. Onco Targets Ther 10, 1645-1653, https://doi.org/10.2147/OTT.S130910 (2017).

84. Kumari, A. et al. Recovery of taste organs and sensory function after severe loss from Hedgehog/Smoothened inhibition with cancer drug sonidegib. Proc Natl Acad Sci USA 114, E10369-E10378, https://doi.org/10.1073/pnas.1712881114 (2017).

85. Metcalfe, C., Kljavin, N. M., Ybarra, R. \& de Sauvage, F. J. Lgr5+ stem cells are indispensable for radiation-induced intestinal regeneration. Cell stem cell 14, 149-159, https://doi.org/10.1016/j.stem.2013.11.008 (2014).

86. Hand, A. R. The fine structure of von Ebner's gland of the rat. The Journal of cell biology 44, 340-353, https://doi.org/10.1083/ jcb.44.2.340 (1970).

87. Sbarbati, A., Crescimanno, C. \& Osculati, F. The anatomy and functional role of the circumvallate papilla/von Ebner gland complex. Med Hypotheses 53, 40-44, https://doi.org/10.1054/mehy.1997.0708 (1999).

88. Treuting, P. M. \& Dintzis, S. M. In Comparative Anatomy and Histology (eds Piper M. Treuting \& Suzanne M. Dintzis) 111-120 (Academic Press, 2012).

89. Matsuo, R. Role of saliva in the maintenance of taste sensitivity. Crit Rev Oral Biol Med 11, 216-229, https://doi.org/10.1177/1045 4411000110020501 (2000).

90. Gurkan, S. \& Bradley, R. M. Secretions of von Ebner's glands influence responses from taste buds in rat circumvallate papilla. Chemical senses 13, 655-661, https://doi.org/10.1093/chemse/13.4.655 (1988).

91. Hand, A. R., Pathmanathan, D. \& Field, R. B. Morphological features of the minor salivary glands. Archives of oral biology 44(Suppl 1), S3-10, https://doi.org/10.1016/s0003-9969(99)90002-x (1999).

92. Sohn, W. J. et al. Morphological evidences in circumvallate papilla and von Ebners' gland development in mice. Anat Cell Biol 44, 274-283, https://doi.org/10.5115/acb.2011.44.4.274 (2011).

93. Spielman, A. I., D’Abundo, S., Field, R. B. \& Schmale, H. Protein analysis of human von Ebner saliva and a method for its collection from the foliate papillae. Journal of dental research 72, 1331-1335, https://doi.org/10.1177/00220345930720091301 (1993).

94. Kock, K., Morley, S. D., Mullins, J. J. \& Schmale, H. Denatonium bitter tasting among transgenic mice expressing rat von Ebner's gland protein. Physiology \& behavior 56, 1173-1177, https://doi.org/10.1016/0031-9384(94)90362-x (1994).

95. Morris-Wiman, J., Sego, R., Brinkley, L. \& Dolce, C. The effects of sialoadenectomy and exogenous EGF on taste bud morphology and maintenance. Chemical senses 25, 9-19, https://doi.org/10.1093/chemse/25.1.9 (2000).

96. Epstein, J. B. et al. Oral complications of cancer and cancer therapy: from cancer treatment to survivorship. CA Cancer J Clin 62, 400-422, https://doi.org/10.3322/caac.21157 (2012).

97. Cohen, E. E. et al. American Cancer Society Head and Neck Cancer Survivorship Care Guideline. CA Cancer J Clin 66, 203-239, https://doi.org/10.3322/caac.21343 (2016).

98. Vissink, A. et al. Clinical management of salivary gland hypofunction and xerostomia in head-and-neck cancer patients: successes and barriers. International journal of radiation oncology, biology, physics 78, 983-991, https://doi.org/10.1016/j.ijrobp.2010.06.052 (2010).

99. Henson, B. S., Eisbruch, A., D'Hondt, E. \& Ship, J. A. Two-year longitudinal study of parotid salivary flow rates in head and neck cancer patients receiving unilateral neck parotid-sparing radiotherapy treatment. Oral oncology 35, 234-241, https://doi. org/10.1016/S1368-8375(98)00104-3 (1999).

100. Humphries, M. J. et al. Suppression of apoptosis in the protein kinase Cdelta null mouse in vivo. The Journal of biological chemistry 281, 9728-9737, https://doi.org/10.1074/jbc.M507851200 (2006).

101. Varghese, J. J. et al. Murine Salivary Functional Assessment via Pilocarpine Stimulation Following Fractionated Radiation. Journal of visualized experiments: JoVE, e57522, https://doi.org/10.3791/57522 (2018).

102. Potten, C. S. et al. Cell kinetic studies in the murine ventral tongue epithelium: mucositis induced by radiation and its protection by pretreatment with keratinocyte growth factor (KGF). Cell proliferation 35(Suppl 1), 32-47, https://doi. org/10.1046/j.1365-2184.35.s1.4.x (2002).

103. Dorr, W., Emmendorfer, H., Haide, E. \& Kummermehr, J. Proliferation equivalent of 'accelerated repopulation' in mouse oral mucosa. Int J Radiat Biol 66, 157-167, https://doi.org/10.1080/09553009414551061 (1994).

104. Luo, J. et al. Smad7 Promotes Healing of Radiotherapy-Induced Oral Mucositis without Compromising Oral Cancer Therapy in a Xenograft Mouse Model. Clin Cancer Res 25, 808-818, https://doi.org/10.1158/1078-0432.CCR-18-1081 (2019).

105. Moses, R. \& Kummermehr, J. Radiation response of the mouse tongue epithelium. Br J Cancer Suppl 7, 12-15 (1986).

106. Spiegelberg, L. et al. Effects of hyperbaric oxygen therapy on the viability of irradiated soft head and neck tissues in mice. Oral Dis 20, e111-119, https://doi.org/10.1111/odi.12162 (2014).

107. Zheng, C. et al. Prevention of radiation-induced oral mucositis after adenoviral vector-mediated transfer of the keratinocyte growth factor cDNA to mouse submandibular glands. Clin Cancer Res 15, 4641-4648, https://doi.org/10.1158/1078-0432.CCR-090819 (2009)

108. de Pedro, I., Alonso-Lecue, P., Sanz-Gomez, N., Freije, A. \& Gandarillas, A. Sublethal UV irradiation induces squamous differentiation via a p53-independent, DNA damage-mitosis checkpoint. Cell Death Dis 9, 1094, https://doi.org/10.1038/s41419018-1130-8 (2018).

109. Gewirtz, D. A. The four faces of autophagy: implications for cancer therapy. Cancer research 74, 647-651, https://doi. org/10.1158/0008-5472.CAN-13-2966 (2014).

110. Hu, L., Wang, H., Huang, L., Zhao, Y. \& Wang, J. Crosstalk between autophagy and intracellular radiation response (Review). Int J Oncol 49, 2217-2226, https://doi.org/10.3892/ijo.2016.3719 (2016).

111. Zois, C. E. \& Koukourakis, M. I. Radiation-induced autophagy in normal and cancer cells: towards novel cytoprotection and radiosensitization policies? Autophagy 5, 442-450, https://doi.org/10.4161/auto.5.4.7667 (2009).

112. Huang, Y. H. et al. Autophagy promotes radiation-induced senescence but inhibits bystander effects in human breast cancer cells. Autophagy 10, 1212-1228, https://doi.org/10.4161/auto.28772 (2014).

113. Wang, Z. et al. Cordycepin prevents radiation ulcer by inhibiting cell senescence via NRF2 and AMPK in rodents. Nature communications 10, 2538, https://doi.org/10.1038/s41467-019-10386-8 (2019).

114. Gu, J. et al. Rapamycin Inhibits Cardiac Hypertrophy by Promoting Autophagy via the MEK/ERK/Beclin-1 Pathway. Front Physiol 7, 104, https://doi.org/10.3389/fphys.2016.00104 (2016)

115. Hrckulak, D., Kolar, M., Strnad, H. \& Korinek, V. TCF/LEF Transcription Factors: An Update from the Internet Resources. Cancers (Basel) 8, 70, https://doi.org/10.3390/cancers8070070 (2016).

116. Mao, C. D. \& Byers, S. W. Cell-context dependent TCF/LEF expression and function: alternative tales of repression, de-repression and activation potentials. Crit Rev Eukaryot Gene Expr 21, 207-236 (2011).

117. Wirsdorfer, F. \& Jendrossek, V. The Role of Lymphocytes in Radiotherapy-Induced Adverse Late Effects in the Lung. Front Immunol 7, 591, https://doi.org/10.3389/fimmu.2016.00591 (2016).

118. Wang, J. F., Liu, C., Zhang, Q. \& Huang, G. H. Research progress in the radioprotective effect of the canonical Wnt pathway. Cancer Biol Med 10, 61-71, https://doi.org/10.7497/j.issn.2095-3941.2013.02.001 (2013).

119. Han, G. et al. Preventive and therapeutic effects of Smad7 on radiation-induced oral mucositis. Nat Med 19, 421-428, https://doi. org $/ 10.1038 / \mathrm{nm} .3118$ (2013).

120. Barlow, L. A. Progress and renewal in gustation: new insights into taste bud development. Development 142, 3620-3629, https:// doi.org/10.1242/dev.120394 (2015). 
121. McLean, I. W. \& Nakane, P. K. Periodate-lysine-paraformaldehyde fixative. A new fixation for immunoelectron microscopy. J Histochem Cytochem 22, 1077-1083, https://doi.org/10.1177/22.12.1077 (1974).

122. Pieri, L., Sassoli, C., Romagnoli, P. \& Domenici, L. Use of periodate-lysine-paraformaldehyde for the fixation of multiple antigens in human skin biopsies. Eur J Histochem 46, 365-375 (2002).

123. Livak, K. J. \& Schmittgen, T. D. Analysis of relative gene expression data using real-time quantitative PCR and the 2(-Delta Delta C(T)) Method. Methods (San Diego, Calif 25, 402-408, https://doi.org/10.1006/meth.2001.1262 (2001).

124. Vandenbeuch, A. et al. Role of the ectonucleotidase NTPDase2 in taste bud function. Proc Natl Acad Sci USA 110, 14789-14794, https://doi.org/10.1073/pnas.1309468110 (2013).

125. Clark, S. P., Ryan, T. P., Searfoss, G. H., Davis, M. A. \& Hooser, S. B. Chronic microcystin exposure induces hepatocyte proliferation with increased expression of mitotic and cyclin-associated genes in P53-deficient mice. Toxicol Pathol 36, 190-203, https://doi. org/10.1177/0192623307311406 (2008).

126. Escobar, D. et al. Sall2 is required for proapoptotic Noxa expression and genotoxic stress-induced apoptosis by doxorubicin. Cell Death Dis 6, e1816, https://doi.org/10.1038/cddis.2015.165 (2015)

127. Radde-Gallwitz, K. et al. Expression of Islet1 marks the sensory and neuronal lineages in the mammalian inner ear. The Journal of comparative neurology 477, 412-421, https://doi.org/10.1002/cne.20257 (2004).

\section{Acknowledgements}

The authors thank Jennifer Scott, Lauren Gross, and Kelly Zaccone for technical support, and Dr. Mary E. Reyland (Department of Craniofacial Biology, University of Colorado Anschutz Medical Campus, CO, USA) for constructive discussions and valuable comments on the manuscript. This work was supported by grants from the National Institutes of Health/National Institute for Deafness and Other Communication Disorders to DG (R21DC016131 \& R21DC016131-02S1) and to LAB (R01DC012383), and from the National Institutes of Health/ National Institute of Dental and Craniofacial Research to SEM (5R01DE024570-04, 1R56DE023100-01A1).

\section{Author contributions}

D.G., S.E.M. and L.A.B. designed the study. D.G. and L.S. performed the experiments, collected and analyzed the data. D.G. and L.A.B. wrote the main manuscript text and prepared the figures. All authors reviewed and edited the manuscript.

\section{Competing interests}

The authors declare no competing interests.

\section{Additional information}

Supplementary information is available for this paper at https://doi.org/10.1038/s41598-019-54216-9.

Correspondence and requests for materials should be addressed to D.G. or L.A.B.

Reprints and permissions information is available at www.nature.com/reprints.

Publisher's note Springer Nature remains neutral with regard to jurisdictional claims in published maps and institutional affiliations.

(c) (i) Open Access This article is licensed under a Creative Commons Attribution 4.0 International License, which permits use, sharing, adaptation, distribution and reproduction in any medium or format, as long as you give appropriate credit to the original author(s) and the source, provide a link to the Creative Commons license, and indicate if changes were made. The images or other third party material in this article are included in the article's Creative Commons license, unless indicated otherwise in a credit line to the material. If material is not included in the article's Creative Commons license and your intended use is not permitted by statutory regulation or exceeds the permitted use, you will need to obtain permission directly from the copyright holder. To view a copy of this license, visit http://creativecommons.org/licenses/by/4.0/.

(C) The Author(s) 2019 